\title{
DISCOVERY IN JAPAN
}

\author{
ANDREW M. PARDIECK*
}

\begin{abstract}
Practitioners and scholars have, for years, extolled the difficulties of discovery in civil litigation in Japan. The Japanese Code of Civil Procedure makes "all information presumptively non-discoverable." In Japan, "nothing is discoverable unless such action is specifically permitted by law." There is no "so-called pretrial discovery as seen in the U.S. system." Those statements, while perhaps once true, no longer reflect litigation as currently practiced. Some twenty years after Japan amended its Code of Civil Procedure to permit greater discovery, civil litigation commonly includes discovery, if defined to include both information and evidence gathering procedures. Litigants seek production of police records, medical records, chat logs, meeting minutes, peer review reports, computer code - the same types of information requested through pre-trial processes in discovery-rich jurisdictions like the United States. How this happens though is markedly different. Japanese law offers a patchwork of discovery devices, scattered across its Code of Civil Procedure and substantive laws. Some are used regularly; some rarely. In most cases, discovery is not self-executing. The Japanese courts act as gatekeepers, and, in doing so, they swing the door to the courthouse open wider in some cases than others. This Article explores the role of discovery in civil litigation and the resource-intensive role of the courts as gatekeepers. It also proposes an alternative: moving from discovery to disclosure in routine litigation.
\end{abstract}

* Andrew M. Pardieck, S.J.D., University of Hokkaido School of Law, Japan; Associate Professor of Law, Southern Illinois University School of Law. With thanks to Professors John Haley, Mark Ramseyer, Mark Levin, Timothy Webster, and other participants for their helpful comments at the 2020 Japanese Law Workshop, 2020 Law \& Society Annual Conference, and 2019 Asian Law \& Society Conference. 


\author{
TABLE OF CONTENTS \\ INTRODUCTION \\ I. DISCOVERY IN JAPAN-A BRIEF HISTORY \\ A. The Old Code of Civil Procedure \\ $B$. Amending the Code of Civil Procedure \\ II. DISCOVERY IN JAPAN-THE CURRENT LEGAL STRUCTURE \\ A. Petition to Preserve Evidence \\ B. Judicial Inquiries \& Court-Commissioned Requests \\ C. Bar Association Requests for Documents \\ D. Petition for Order for Production of Documents \\ E. Other Methods \\ 1. Interrogatory-Type Requests \\ 2. Pre-Suit Discovery \\ 3. Discovery in Intellectual Property Cases \\ III. DISCOVERY IN JAPAN-THE RULES IN PRACTICE \\ A. Judicial Inquiries \& Burdens of Proof \\ B. Court Commissioned Requests \\ C. Bar Association Requests for Information \\ D. Preservation Orders \\ E. Orders to Produce Documents \\ V. CONCLUSION
}

\title{
I. INTRODUCTION
}

Practitioners and scholars have, for years, extolled the difficulties of discovery in Japan. " "[T]here is virtually no discovery in Japan." ${ }^{1}$ The Japanese Code of Civil Procedure makes "all information presumptively nondiscoverable." In Japan, "nothing is discoverable unless such action is specifically permitted by law." Once a trial has started, "authority and control

1. See, e.g., Craig P. Wagnild, Civil Law Discovery in Japan: A Comparison of Japanese and U.S. Methods of Evidence Collection in Civil Litigation, 3 Asian-PaC. L. \& PoL'y J. 1, 3 (2002). See also Lucille M. Ponte, Guilt by Association in United States Products Liability Cases: Are the European Community and Japan Likely to Develop Similar Cause-in-Fact Approaches to Defendant Identification?, 15 OY. L.A. INT'L \& CoMP. L. J. 629, 630 (1993); James A. Forstner, Patent Litigation in Japan, China, And Korea, 366 PLi/Pat 13, 15 (1993).

2. Steven Comer \& Chie Yakura, Litigation in Japan, AM. LAWYER, Oct. 2014, at 23.

3. Toshihiro M. Mochizuki, Baby Step or Giant Leap?: Parties' Expanded Access to Documentary Evidence Under the New Japanese Code of Civil Procedure, 40 HARV. InT'L L. J. 285, 287 (1999).

4. Joseph W.S. Davis \& Yoshikaza Takaishi, Dispute Resolution In Japan 214-15 (1996); see also Itsuko Mori, The Difference Between U.S. Discovery and Japanese Taking of Evidence, 23 INT'L LAW 3 (1989) ([T]here is no "so-called pretrial discovery as seen in the U.S. system. The only way in Japan to gather evidentiary facts before initiation of the trial is to resort to the special procedure available for preservation of evidence.”). 
over the gathering of evidentiary facts are vested only in a court ... Such power will never be used for any purpose other than for collection of evidence for use in the civil trial.".

Comparative law scholars suggest Japan is like "most other civil law countries," where there is "no pretrial document production conducted by the lawyers. A party can request the court to require the opposing party to produce documents, but . . . the opposing party cannot be compelled to produce [a] document that will establish liability against him," or "a party may be compelled to produce a document [only] when the judge concludes that the document is the only evidence concerning the point in issue." ${ }^{7}$

Those statements, while perhaps once true, no longer reflect civil litigation as it is currently practiced in Japan. Some twenty years after Japan amended its Code of Civil Procedure to permit greater discovery, civil litigation commonly includes discovery. Litigants seek production of police records, medical records, chat logs, meeting minutes, peer review reports, computer code - the same types of information requested through pre-trial processes in discovery-rich jurisdictions like the United States. ${ }^{8}$

How this happens in Japan though is markedly different. Japanese law offers a patchwork of discovery devices scattered across its Code of Civil Procedure and various substantive laws. Some are intended to examine evidence during trial proceedings; others are designed to discover relevant information prior to the complaint, in court hearings, or when executing a judgment. Some are used regularly; some rarely. In most cases though, discovery is not self-executing, and it is not trans-substantive. ${ }^{9}$ The Japanese courts act as gatekeepers, and they open the door wider in some cases than others. ${ }^{10}$

The extent of court involvement is remarkable. Whether born of a deepseated mistrust of the discovery process or deep-seated confidence in the Japanese judiciary, the drafters of Japan's discovery rules have involved the judiciary at almost every step. The judiciary grants or denies petitions to issue pre-complaint discovery. They grant or deny petitions to order the preservation of documents and testimony. After the complaint is filed, they grant or deny petitions to issue requests that a party voluntarily produce information. They grant or deny petitions to issue requests that a party voluntarily produce documents. They grant or deny petitions to order the production of documents. ${ }^{11}$

The extent of judicial involvement determines the extent of the discovery,

5. Mori, supra note 4, at 3-4.

6. Shozo Ota, Reform of Civil Procedure in Japan, AM. J. CoMP. L. 561, 561 (2001).

7. Stephen N. Subrin, Discovery in a Global Perspective: Are We Nuts?, 52 DePaul L. REV. 299, 302 (2002). An exception to these general statements can be found in a detailed examination of fact-finding in civil litigation in Japan in Kuo-Chang Huang, InTroducing Discovery INTO Civil LAW 109-210 (2003).

8. See infra Part IV.

9. See infra Part III.

10. See infra Part III.

11. See infra Part III. 
and, in most cases, there are not enough resources to litigate discovery. The judiciary remains overworked ${ }^{12}$ and unreceptive to contested discovery unless it is "indispensable." 13 Instead, attorneys rely on publicly available information and "voluntary" disclosure. They follow on the heels of administrative and criminal investigations. ${ }^{14}$ They rely on bar association-mediated requests for information, and they seek to "clarify" the facts during the trial process. ${ }^{15}$

As difficult as discovery in Japan is though, it can no longer be ignored. The courts are now full of discovery disputes, and Japan's Supreme Court regularly weighs in on them. In the twenty years since Japan adopted its amended Code of Civil Procedure, Japan's Supreme Court has handed down thirty decisions addressing the scope of discovery, ${ }^{16}$ and most of these decisions are rulings on production of documents. ${ }^{17}$

Even if court-ordered discovery is still rare, it matters. It matters because it arises in and decides high-stakes litigation. It is the court order on a request for production that disgorges, or not, incident reports in the medical malpractice case $;{ }^{18}$ chat $\log$ in the IP case $;{ }^{19}$ timecards in the overtime case $;{ }^{20}$ and accident

12. "The caseload for lower court judges is enormous. On average Japanese district court judges (including assistant judges) decide over 1100 civil, administrative, and criminal cases per judge per year." John Haley et al., The Japanese Judiciary: Maintaining Integrity, Autonomy and the Public Trust 4, in LAW In JAPAN: A TURnING PoInT (Daniel J. Foote, ed., 2007), https://papers. ssrn.com/sol3/papers.cfm?abstract_id=821466 [perma https://perma.cc/J7VD-YGSR]. In 2018, approximately 623,000 cases were filed in the district and appellate courts to be decided by 2,251 judges. See infra text accompanying notes 475-76.

13. See infra text accompanying note 254 .

14. Securities litigation offers an example. As of September 2018, every case filed seeking damages for fraudulent misstatements in securities filings followed either a criminal prosecution of the issuer, officer, or director or a civil investigation and administrative penalties imposed by Japan's Securities Exchange Surveillance Commission. SAKurai Takeo et al., Shin Kinyū SHounin Torihiki Hou HandobukKu 83 (4th ed. 2018). The criminal and administrative actions led to civil litigation involving almost 5,000 plaintiffs. Goto, Gen, Growing Securities Litigation Against Issuers in Japan: Its Background and Reality Table 2 (Jan. 12, 2016), available at https://ssrn.com/abstract=2714252 or http://dx.doi.org/10.2139/ssrn.2714252.

15. See infra Part III.

16. See, e.g., infra text accompanying notes 459-68; Saibanrei Jōhō, http://www.courts. go.jp/.

17. Shiro Kawashima, Daihyō Soshō to Bunsho Teishutsu Meirei Seido, 62 Doshisha L. REV. (6) 1687, 1688 (Mar. 2011).

18. Tōkyō Kōsai [Tōkyō High Ct.] July 15, 2003, Hei 15 (ra) nos. 831 \& 900, 1145, HANREI TAIMUZU [HANTA] 298; see also Robert B. Leflar, The Law of Medical Misadventure in Japan, 87 Chi-Kent L. Rev. 79, 100 (2012).

19. Chiteki Zaisan Kōtō Saibansho [Intellectual Property High Ct.] Aug. 8, 2016, Hei 28 (u) no. 10038 .

20. Osaka Kōtō Saibansho [Osaka High Ct.] July 18, 2013, Hei 25 (ra) no. 565, 2224, HANREI JIHŌ [HANJI] 52. 
reports in the wrongful death case. ${ }^{21}$ It is the court order on a petition to order production that discloses, or not, the employer's investigation report in the sexual harassment suit; ${ }^{22}$ and the photographs in the products liability case. ${ }^{23}$

It is the court order on a petition for production that discloses, or not, the expense reports for local politicians wining and dining on the taxpayer's yen; ${ }^{24}$ the warrants and supporting documents in the wrongful arrest case; ${ }^{25}$ and the safety records in the nuclear power plant injunction cases. ${ }^{26}$ In other words, the courts in Japan now routinely decide discovery disputes in complex litigation addressing significant legal and social issues, and the Japanese Supreme Court controls access to justice through its discovery rulings.

This study explores the evolving role of discovery in civil litigation in Japan, and the courts' efforts to act as a gatekeeper. Part II explores the historical development of the Code of Civil Procedure's discovery provisions-defined here to include both "information gathering" procedures used by litigants, as well as the "evidence examination" procedures co-opted by litigants to discover information. $^{27}$ In doing so, this section provides context for, and then a discussion of, the 1996 amendments to the Code of Civil Procedure. Those amendments, effective 1998, changed the litigation landscape in Japan. ${ }^{28}$

Part III of this Article describes the "information gathering" and "evidence examination" procedures that currently exist. It focuses on the legal structure for written discovery in Japan and explores the means to produce the types of

21. Saikō Saibansho [Sup. Ct.] Oct. 14, 2005, Hei 17 (kyo) no. 11, 59 SAIKō SAIBANSho MINJI HANREISHŪ [MINSHŪ] (No. 8) 2265.

22. Saikō Saibansho [Sup. Ct.] Dec. 19, 2013, Hei 25 (kyo) no. 6, 1423 HANRei TAimuzu [HANTA] 138.

23. Nayoga Chihō Saibansho [Nagoya Dist. Ct.] Nov. 17, 2008, Hei 19 (mo) no. 697, 1333 HANREI TAIMUZU [HANTA] 270.

24. Saikō Saibansho [Sup. Ct.] Oct. 29, 2014, Hei 26 (gyou-fu) no. 3, 2247 HANREI TAIMUZU [Hanta] 3; see Saikō Saibansho [Sup. Ct.] Nov. 10, 2005, Hei 17 (gyou-fu) no. 2, 1210 HanreI TAIMUZU [HANTA] 72.

25. See Saikō Saibansho [Sup. Ct.] July 22, 2005, Hei 17 (kyo) no. 4, 1191 HANREI TAIMUZU [Hanta] 230; Saikō Saibansho [Sup. Ct.] Dec. 12, 2007, Hei 19 (kyo) no. 22, 1261 Hanrei TAIMUZU [HANTA] 155.

26. Tōkyō Kōtō Saibansho [Tōkyō High Ct.] May 21, 1993, Hei 5 (ra) no. 82; Tōkyō Chihō Saibansho [Tōkyō Dist. Ct.] Jan. 22, 1993 Hei 4 (mo) no. 5700; Shizuoka Chihō Saibansho [Shizuoka Dist. Ct.] Mar. 16, 2005, Hei 16 (Mo) no. 25.

27. Some distinguish between procedures to collect information and procedures to obtain evidence and call neither "discovery." See, e.g., Joseph W.S. DAvis, Dispute Resolution IN JAPAN 214-15 (1996); Mochizuki, supra note 3, at 286 n.7. Practitioners report routinely utilizing procedures designed to obtain evidence for use at trial as a means to discover relevant information. Interview with Osaka attorney (Dec. 15, 2019) (notes on file with author); Interview with Osaka attorneys (Dec. 16, 2019) (notes on file with author); Interview with Kyoto attorneys (Dec. 17, 2019) (notes on file with author) [hereinafter attorney interviews].

28. Takeshi Kojima, Japanese Civil Procedure in Comparative Perspective, 46 U. KAN. L. REV. 687, 691 (1998); Mochizuki, supra note 3, at 286. 
information typically sought in interrogatories and requests for production found in the United States. In Japan, that requires an exploration of dozens of different procedural devices, some found in the Code of Civil Procedure and some in special discovery rules in various substantive laws. Part IV discusses the practical implications of the current discovery framework. It examines the data on discovery practice in Japan, as well as practitioner commentary. While incomplete, the available information paints a good picture of how discovery works, or does not, in Japan.

There is much more going on than the common platitudes that there is no discovery in Japan. The research makes clear that discovery is now part-in-parcel of most civil litigation in Japan. But the type of discovery varies dramatically, and it is not what one would expect from the rules. The Code of Civil Procedure, and a variety of substantive laws, offer the tatemae, an "official stance," that litigants have numerous means to discover evidence, including far broader precomplaint discovery than found in most U.S. jurisdictions. ${ }^{29}$ The honne, or real intention, is more complicated. ${ }^{30}$ Some of these rules are all but dead letter. Some are indispensable. This Article distinguishes between the two and concludes by examining the significance of the rules and their application, and it suggests an alternative, a better way.

\section{DISCOVERY IN JAPAN—A BRIEF HISTORY}

\section{A. The Old Code of Civil Procedure}

As originally adopted in 1890, Japan's Code of Civil Procedure was "basically a translation of the German Code of Civil Procedure." 31 It provided for piecemeal hearings, no "trial", and "very limited" discovery. ${ }^{32}$ In 1926, the Japanese Diet amended the code to "streamline" it," and make substantive changes to the summary, appeals, and re-trial procedures. ${ }^{34}$ After World War II, Japan amended its code again to incorporate elements of U.S. procedure. ${ }^{35}$ But the changes were again limited: they added special procedures for summary

29. Tatemae is commonly translated as "the official stance; public position; or attitude." See Jim Breen, WWWJDIC: Online Japanese Dictionary Service, WWWJDIC, https://wwwjdic.org (last visited July 15, 2019).

30. Honne is commonly translated as the "real intention; motive; true opinion." See id.

31. Ota, supra note 6, at 563. Boissonade drafted a Code of Civil Procedure based on the French Code.

Techow completely reworked the draft based on the German code of civil procedure, which the Japanese government adopted. See generally Michael Young \& Constance Hamilton, Historical Introduction to the Japanese Legal System, JAPAN Bus. L. GuIDE $91-770$ (1988).

32. Kojima, supra note 28, at 689; Yasuhei Taniguchi, The 1996 Code of Civil Procedure of Japan-A Procedure for the Coming Century?, 45 Aм. J. Comp. L. 767 (1997).

33. Ota, supra note 6 , at 563.

34. See generally Young \& Hamilton, supra note 31.

35. Ota, supra note 6, at 563. 
courts and appeals, eliminated the ex officio examination of evidence, and introduced cross-examination procedures. They did not add pre-trial discovery. ${ }^{36}$

The original code remained largely intact for over one hundred years, ${ }^{37}$ and that proved problematic. ${ }^{38}$ Critics argued the 1890 code was designed to resolve civil disputes between private individuals, and it was ill-suited to resolve the complex litigation that arose with industrialization after World War II. ${ }^{39}$ With increasing numbers of environmental pollution, products liability, and other complex cases,${ }^{40}$ critics charged the courts were failing to resolve disputes "fairly and expeditiously," ${ }^{41}$ and disputants began taking their disputes elsewhere (shiho banare). ${ }^{42}$ While the economy and population grew rapidly, the number of cases filed in the courts remained about the same as when the code was first adopted 100 years ago. ${ }^{43}$

One problem was delay, even simple cases took years to resolve. ${ }^{44}$ Another problem was discovery, or the absence thereof. ${ }^{45}$ Complex litigation is often asymmetric litigation, with one party possessing most of the relevant evidence, and, while the 1890 code imposed a general duty on witnesses to appear to testify, it imposed no such general duty to produce relevant documents. ${ }^{46}$

The 1890 code recognized a duty to produce only certain types of documents. A person could not refuse to submit a document to the court:

(i) if a party is personally in possession of a document that the party has cited in litigation;

(ii) if it is permissible for the party that will offer the evidence to request the person in possession of the document to deliver it or allow it to be inspected;

(iii) if the document has been prepared in the interest of the party that will offer the evidence or with regard to the legal relationships between the party that will offer the evidence and the person in possession of the

36. Id. at 563-64.

37. Kojima, supra note 28, at 693.

38. Id. at 687.

39. Ota, supra note 6 , at 565 .

40. Id.; Nako Michitaka, Rōdō Jiken to Bunsho Teishutsu Meirei - Futatsu no Hanrei wo Chūshin ni Shite, 61 KanAZAwa L. Rev. (No. 1), 33-58 (2018).

41. Minjı Soshōhō [Minsohō] [C. Civ. Pro.], Law No. 109 of 1996, art. 2, translated in JAPANESE L. TRANS., http://www.japaneselawtranslation.go.jp/law/detail/?printID=\&ft=2\&re= $2 \& \mathrm{dn}=1 \& \mathrm{yo}=\% \mathrm{E} 6 \% \mathrm{~B} 0 \% 91 \% \mathrm{E} 4 \% \mathrm{BA} \% 8 \mathrm{~B} \% \mathrm{E} 8 \% \mathrm{~A} 8 \% \mathrm{~B} 4 \% \mathrm{E} 8 \% \mathrm{~A} 8 \% 9 \mathrm{~F} \% \mathrm{E} 6 \% \mathrm{~B} 3 \% 95 \& \mathrm{x}=48$ $\& \mathrm{y}=10 \& \mathrm{ia}=03 \& \mathrm{ph}=\& \mathrm{ky}=\&$ page $=1 \& \mathrm{vm}=02$ [https://perma.cc/A6TA-6WDU].

42. Kojima, supra note 28 , at 688 .

43. Id.

44. Id. at 689-90.

45. See id. at 691-92.

46. Kouichi Miki, Minji Soshounou 320 (Yuikaku Legal Quest 3rd ed. 2018); Michitaka, supra note 40 , at 4 . 
document. ${ }^{47}$

In short, courts required production of only four types of documents: (i) those cited by a party in the judicial proceedings in question; (ii) those the requesting party had a legal right to inspect or request copies of; and, in section (iii), those documents defining either (a) a legally recognized beneficiary interest held by the requesting party or (b) a legal relationship between the party presenting the proof and the possessor of the document.

These same categories are found in the current code. Courts now define "cited documents" to include those documents "voluntarily and affirmatively" referenced by the responding party in litigation. ${ }^{48}$ Where a party does no more than admit to the existence of the document during an examination by the judge, the courts have held that this section does not provide a right of discovery. ${ }^{49}$ The courts have split on which statutes give rise to a legal right to demand or inspect the document. Some courts have limited the application of this section to private law statutes, e.g., a shareholder's right to inspect the articles of incorporation and company register. They exclude from its purview public law statutes creating a right to inspect government documents. ${ }^{50}$

Whether interpreted broadly or narrowly, both sections (i) and (ii) are capable of relatively objective application. ${ }^{51}$ In contrast, the courts have struggled to define section (iii). Traditionally, documents defining a beneficial interest included documents such as wills, contracts, power of attorney documents, and the like. ${ }^{52}$ They were documents created to define a proponent's rights, benefits, or authority. ${ }^{53}$ Traditionally, documents defining a legal relationship were those that directly defined legal rights and obligations held by the proponent vis-à-vis the possessor of the document, e.g., contracts, letters of acceptance, rental accounting ledgers (yachin ts $\bar{u} c h \bar{o})$, termination notices, and certificates registering seal imprints (inkan shōmeisho). ${ }^{54}$

As litigation changed, both litigants and the courts attempted to work around these limitations. ${ }^{55}$ A Tokyo High Court decision from the early 1990 s re-defined a beneficial interest document to include "a document that . . . is foundational to the proponent's legal position, rights or authority, and the document in question

47. Minsohō (C. Civ. Pro.) art. 220.

48. Takaomi Takizawa, Bunsho Teishutsu Meirei (1), BUs. L. J. 107 (Lexis Japan Feb. 2017).

49. Id. (citing Tōkyō Kōtō Saibansho [Tōkyō High Ct.] May 20, 1965, 178 Hanrei TaimuzU [HANTA] 147.

50. Id. at 109 (citing Tōkyō Kōtō Saibansho [Tōkyō High Ct.] Mar. 31, 1993, 115 Hanrei CHIHŌ JiChi [HANREI JiCHI] 11 (holding that this section of the Code of Civil Procedure does not create a right to demand production of government documents pursuant to a public disclosure ordinance).

51. Takizawa, Bunsho Teishutsu Meirei (1), supra note 48, at 109.

52. Michitaka, supra note 40 , at 3.

53. Id.

54. Id.

55. Id.; Kojima, supra note 28, at 703; Mochizuki, supra note 3, at 290-91. 
was created with that purpose." ${ }^{, 56}$ In mass tort litigation, defendant pharmaceutical companies used this definition to seek plaintiffs' medical records, and courts agreed, finding such documents indirectly defined a proponent's interests. ${ }^{57}$

Legal relationship documents similarly grew in scope. An Osaka High Court decision from shortly before the 1996 amendments held that, in deciding whether a document was a "legal relationship document," one should examine:

whether the document . . . defines a specific legal relationship between the proponent and the possessor of the documents ... or whether there are specific facts and the like contained therein which directly prove or disprove required elements of the legal relationship in question, or facts that are indirectly related to the legal relationship in question. ${ }^{58}$

Expanding the definitions changed things. Following the crash of a Self Defense Force jet, decedents of the pilot brought a wrongful death action against the State and sought production of its accident investigation report. The court found the report both a "beneficial interest" document and a "legal relationship" document, as it included facts related to the parties' legal rights and obligations. After the Self Defense Force refused to produce the report, the court entered judgment on the merits for the plaintiff. ${ }^{59}$

Documents containing facts that indirectly relate to a beneficiary interest or legal relationship could conceivably include any document relevant to the legal issues in dispute. Statutory language defining a narrow category of documents had turned into a relevancy standard, and the courts split on how broadly to apply it.

Some courts limited the doctrine by holding that just because the document would "facilitate proof of the petitioner's case," it would not, ipso facto, make the document a legal relationship document. ${ }^{60}$ Other courts began to develop an "internal use document" (jiko shiyo bunsho) exception, a doctrine not found in other civil law jurisdictions. ${ }^{61}$ If a document was prepared solely for the internal use of the possessor of the document, it could not, by definition, have been prepared to create or define the legal interests of the opposing party. The courts found, and still hold, that the two concepts are mutually exclusive. ${ }^{62}$

With increasing divergence among the courts defining the types of documents

56. Takizawa, Bunsho Teishutsu Meirei (1), supra note 48, at 110-11.

57. Michitaka, supra note 40, at 6.

58. Takizawa, Bunsho Teishutsu Meirei (1), supra note 48, at 111 (emphasis added). See also Michitaka, supra note 40, at 4.

59. Taniguchi, supra note 33, at 776.

60. Takizawa, Bunsho Teishutsu Meirei (1), supra note 48, at 111.

61. Toshikatsa Tomizawa, Kigyōnai Bunsho no Teishutsu Gimu Ni Tsuite, 35 YamagatA DAigaKu KiYou (No. 2) 15, 17 (2019); Michitaka, supra note 40, at 4; Mochizuki, supra note 3, at 292-93.

62. Saikō Saibansho [Sup. Ct.] Oct. 11, 2011, Hei 23 (kyo) no. 42, 1362 Hanrei TAimuzU [HANTA] 68. 
to be produced and increasing dissatisfaction with the judiciary's attempts to resolve the complex litigation found in post-World War II Japan, came increasing calls to amend Japan's Code of Civil Procedure. ${ }^{63}$

\section{B. Amending the Code of Civil Procedure}

There were early ad hoc attempts by the judges and attorneys that gained little traction. ${ }^{64}$ Things changed when the Ministry of Justice got involved. ${ }^{65}$ In 1990, it established a sub-committee on civil procedure in the Ministry's Deliberative Council on the Legal System. ${ }^{66}$ The chair bridged the divide between a conservative bureaucracy and a liberal bar by appointing a committee of three judges, three practicing attorneys, and three scholars ${ }^{67}$ Drafts followed in 1993 and early $1996 .{ }^{68}$ Following a public comment period, the Ministry of Justice submitted its final version to the Diet in March 1996. ${ }^{69}$

Through the amendments, the Ministry sought to promulgate "civil litigation procedures that are responsive to the needs of society, make civil litigation readily understood and usable for the people, and realize fair and efficient trials." 70 The amendments sought to streamline issue management procedures, expand evidence-gathering procedures, introduce a special small claims procedure, and restrict rights of appeal to Japan's Supreme Court. ${ }^{71}$

Debate focused on the discovery amendments. ${ }^{72}$ For the first time, the draft code authorized interrogatory-type requests modeled, in part, on the interrogatories found in the United States. For the first time, the code imposed a general duty on litigants to produce documents. ${ }^{73}$ For the first time, the Civil Litigation Rules required litigants to state, in writing, the basis for any denial of an opposing party's factual allegation. ${ }^{74}$

63. Ota, supra note 6, at 565-66.

64. Id.

65. Id. at 566.

66. Id.

67. Id.

68. Id. at 567.

69. Id.

70. Hōmusho Minjikyoku Sanjikanshitsu, ICHIMON ItTō SHIN MinjI SoshōHō 5 (Shouji Houmu Kenkyūkai 1996); Kenichiro Tsuda (Tōkyō Bar Attorney), Minji Saiban ni Okeru Jōhō/Shōko Shūshuu Hōhō no Kakuritsu ni Mukete, Shinpojium Kichō Hōkoku 2 (Sept. 4, 2019), https://www.nichibenren.or.jp/library/ja/publication/booklet/data/symposium.pdf [https://perma.cc/874B-YFVY] [hereinafter Nichibenren Keynote Report].

71. Ota, supra note 6, at 568-72; Mochizuki, supra note 3, at 295.

72. Ota, supra note 6, at 567; Hōmusho Minjikyoku Sanjikanshitsu, supra note 70, at 5; Nichibenren Keynote Report, supra note 70, at 2.

73. Nichibenren, Minji Saiban ni Okeru Jouhou /Shouko Shuushuu Houhou no Kakuritsu ni Mukete, Shinpojium Hōkokusho at 3 (Sept. 4, 2019) [hereinafter Nichibenren Symposium Report], available at https://www.nichibenren.or.jp/library/ja/publication/booklet/data/symposium.pdf.

74. Minjı SoshōHō [Minsohō] [C.Civ.Pro.], Law No. 109 of 1996, art. 53, translated in 
Scholars heralded the amendments as marking a fundamental change, recognizing that it is "inappropriate (unjust and unfair) for a litigant to win simply on the chance the other side lacks basic information." 75 They suggested that the amendments to the code were intended to level the playing field. ${ }^{76}$

Industry and the government were less enthusiastic. ${ }^{77}$ While judicial reform had traditionally remained the province of "the 'petit triangle' composed of the court (the Supreme Court), the Japanese Federation of Bar Associations (Nichibenren), and the Ministry of Justice," 78 with these reforms, business organizations entered the fray ${ }^{79}$ Business organizations sought to limit the general duty to produce documents through codification of the internal use doctrine discussed above. ${ }^{80}$ They succeeded, by pushing a last-minute compromise between those in the Diet who advocated dramatically expanding pre-trial discovery, and those who opposed it. ${ }^{81}$

Government opposition to a broader duty to produce documents produced another negotiated compromise. The 1996 Ministry of Justice draft all but eliminated discovery of documents maintained by the government. ${ }^{82}$ It required production of government documents containing confidential information to be approved by the supervising administrative agency, e.g., the House of Representatives for confidential information held by a representative and the Cabinet for confidential information held by the Office of the Prime Minister. ${ }^{83}$ After mounting criticism, the Diet deleted this section and, instead, added a rule requiring further study of a disclosure system for information possessed by government entities. ${ }^{84}$

With these compromises in place, in August 1996, the Japanese Diet passed

JAPANESE L. TRANS., http://www.japaneselawtranslation.go.jp/law/detail/?printID=\&ft=2\&re=2\& $\mathrm{dn}=1 \& \mathrm{yo}=\% \mathrm{E} 6 \% \mathrm{~B} 0 \% 91 \% \mathrm{E} 4 \% \mathrm{BA} \% 8 \mathrm{~B} \% \mathrm{E} 8 \% \mathrm{~A} 8 \% \mathrm{~B} 4 \% \mathrm{E} 8 \% \mathrm{~A} 8 \% 9 \mathrm{~F} \% \mathrm{E} 6 \% \mathrm{~B} 3 \% 95 \& \mathrm{x}=48 \& \mathrm{y}=$ $10 \& \mathrm{ia}=03 \& \mathrm{ph}=\& \mathrm{ky}=\& \mathrm{page}=1 \& \mathrm{vm}=02$ ) [https:/perma.cc/A6TA-6WDU]; MinJI SoshŌ KISOKU [Civil Litigation Rules] art. 53; Nichibenren Keynote Report, supra note 70, at 2. In anticipation of the broader disclosure of information, the amendments permit courts to limit public review of court records in order to protect confidential information filed with the court. Takaharu Totsuka, Minji Soshō Hō Jo no Bunshō Teishutsu Gimu ni Tsuite: Shōgen/Bunsho Teishutsu nado ni Kansuru Hoka no Seido to Hikaku Shiten wo Koete, KINYŪ KENKYŪ 154 (Nihon Ginkō Kinyū Kenkyūjō Mar. 1999).

75. Nichibenren Keynote Report, supra note 70, at 2.

76. Kawashima, supra note 17 , at 1688.

77. Ota, supra note 6, at 583; Taniguchi, supra note 32 , at 776.

78. Ota, supra note 6 , at 583.

79. See id.

80. Tomizawa, supra note 61, at 18; Mochizuki, supra note 3, at 299.

81. Tomizawa, supra note 61, at 18; Mochizuki, supra note 3, 298-99; Taniguchi, supra note 32, at 777 .

82. Mochizuki, supra note 3, at 309-10; Totsuka, supra note 74, at 154. See Kojima, supra note 28 , at 703 .

83. Mochizuki, supra note 3, at 309-10.

84. Totsuka, supra note 74 , at 154. 
legislation adopting the modified draft, including the new discovery devices. ${ }^{85}$ The amendments went into effect January $1,1998{ }^{86}$

Around the same time, over 1,800 hemophiliacs and their families were litigating claims against the Japanese government and five pharmaceutical companies alleging that the government and companies had knowingly distributed tainted blood products infecting them with HIV. ${ }^{87}$ Their proof came from Freedom of Information Act (FOIA) requests in the United States, not discovery in Japan. ${ }^{88}$ That scandal and the inability of the Japanese courts to render justice provided impetus for further reform. The Ministry of Justice completed study of a disclosure system for government information, and, in 2001, the Diet amended the code again adding discovery rules for production of government documents, with more narrowly defined exceptions for confidential information. ${ }^{89}$

Government agencies promptly began issuing administrative guidance on the subject. The Ministry of Health, Labor and Welfare, for example, issued a notice requiring its employees to investigate whether production of any documents would violate individual privacy rights or interfere with government functions, and, if not, in principle, produce the documents requested. ${ }^{90}$ It went on to define certain types of documents, such as accident and disaster investigation reports that, in principle, contained private information and, except for objective factual summaries, were not to be produced. ${ }^{11}$

The debate continued, and, in 2003, the Diet again amended the code to include two new, pre-complaint discovery devices. ${ }^{92}$ Proposed by scholars still advocating U.S.-style discovery and opposed by business, ${ }^{93}$ the 2003 amendments offered another comprise, creating the first "true" discovery devices, as opposed to devices intended to examine evidence during trial proceedings. ${ }^{94}$ This

85. Ota, supra note 6, at 561.

86. See generally Minji SoshōHō [Minsohō][C.Civ.Pro.], Law No. 109 of 1996, translated in JAPANESE L. TRANS., http://www.japaneselawtranslation.go.jp/law/detail/?printID=\&ft=2\&re= $2 \& \mathrm{dn}=1 \& \mathrm{yo}=\% \mathrm{E} 6 \% \mathrm{~B} 0 \% 91 \% \mathrm{E} 4 \% \mathrm{BA} \% 8 \mathrm{~B} \% \mathrm{E} 8 \% \mathrm{~A} 8 \% \mathrm{~B} 4 \% \mathrm{E} 8 \% \mathrm{~A} 8 \% 9 \mathrm{~F} \% \mathrm{E} 6 \% \mathrm{~B} 3 \% 95 \& \mathrm{x}=48$ $\& \mathrm{y}=10 \& \mathrm{ia}=03 \& \mathrm{ph}=\& \mathrm{ky}=\&$ page $=1 \& \mathrm{vm}=02$ [https:/perma.cc/A6TA-6WDU].

87. Mochizuki, supra note 3 , at 285.

88. Id. at 286 .

89. Totsuka, supra note 74, at 154.

90. Min. of Health, Labour and Welfare, Saibansho nado kara no Bunsho Teishutsu Meirei nado ni taisuru Toriatsukai ni tsuite (Kihatsu No. 0313008) (Mar. 13, 2002).

91. Id.

92. Nichibenren Symposium Report, supra note 73, at 7.

93. Attorney interviews, supra note 27.

94. Minjı SoshōHō [Minsohō] [C.Civ.Pro.], Law No. 109 of 1996, art. 132-2 to 132-9 (Chapter VI Dispositions on the Collection of Evidence Prior to the Filing of an Action), translated in JAPANESE L. TRANS., http://www.japaneselawtranslation.go.jp/law/detail/?printID=\&ft=2\&re= $2 \& \mathrm{dn}=1 \& \mathrm{yo}=\% \mathrm{E} 6 \% \mathrm{~B} 0 \% 91 \% \mathrm{E} 4 \% \mathrm{BA} \% 8 \mathrm{~B} \% \mathrm{E} 8 \% \mathrm{~A} 8 \% \mathrm{~B} 4 \% \mathrm{E} 8 \% \mathrm{~A} 8 \% 9 \mathrm{~F} \% \mathrm{E} 6 \% \mathrm{~B} 3 \% 95 \& \mathrm{x}=48$ $\& \mathrm{y}=10 \& \mathrm{ia}=03 \& \mathrm{ph}=\& \mathrm{ky}=\&$ page $=1 \& \mathrm{vm}=02$ [https:/perma.cc/A6TA-6WDU]; Kazutoshi Otsubo, Utae no Teikimae ni Okeru Shōho Shūshū no Shobun nado, 8 LIBRA (No. 10) 16 (2008). 
legislation added a chapter to the "General Rules" section of code broadly titled "Dispositions on the Collection of Evidence Prior to the Filing of an Action," but, as discussed below, this "discovery" offered little to commend it.

\section{DISCOVERY IN JAPAN—THE CURRENT LEGAL STRUCTURE}

At this point, discovery in civil litigation in Japan takes varied forms, united only by an ambiguity of standards and complexity of procedure. Setting aside informal discovery, the Code of Civil Procedure now authorizes over a dozen different methods by which litigants may discover information and documents.

Prior to filing a complaint, parties to a dispute may petition the court for an order to preserve evidence (shōko hozen); ${ }^{96}$ propound interrogatory-type questions (teisomae shōkai); or petition the court to commission production of evidence (teisomae shōko shūshū shobun), including documents, ${ }^{97}$ information from an organization or entity, ${ }^{98}$ expert statements, ${ }^{99}$ and site or object inspections. ${ }^{100}$

After the complaint is filed, the parties may, again, seek preservation orders. ${ }^{101}$ Separate statutes then permit parties to propound interrogatory-type requests (töjisha shōkai), ${ }^{102}$ and petition the court to commission production of information (chōsa shokutaku), ${ }^{103}$ documents (bunsho sōfu shokutaku) ${ }^{104}$ oral or written expert statements (kantei no chinjutsu), ${ }^{105}$ and site or object inspections $(k e n s h \bar{o}) .{ }^{106}$ In addition, a litigant may petition the court to order production of documents (bunsho teishutsu meirei). ${ }^{107}$ Once the court has begun hearings on the matter, parties may then petition the court to exercise its authority to clarify disputed matters (shakumeiken). ${ }^{108}$ They may do so at the hearing or by written request petitioning the court to call certain witnesses or encourage production of certain evidence. ${ }^{109}$

Apart from the Code of Civil Procedure, numerous special laws, addressing both substance and procedure, authorize additional discovery measures. The Attorney Act authorizes an attorney, representing a party to a dispute, to petition

\footnotetext{
95. Minsohō (C. Cıv. Pro.) arts. 132-2 to 132-9; Otsubo, supra note 94, at 16.

96. Minsohō (C. Civ. Pro.) art. 234-42.

97. Id. art. 132-4(i).

98. Id. art. 132-4(ii).

99. Id. art. 132-4(ii).

100. Id. art. 132-4(iii).

101. Id. art. 234-242.

102. Id. art. 163.

103. Id. art. 186.

104. Id. art. 226.

105. Id. art. 215.

106. Id. art. 233.

107. Id. art. 221.

108. Id. art. 149.

109. Id.
} 
his or her bar association to request the association commission production of information related to a dispute (bengoshikai shōkai). ${ }^{110}$ Japan's intellectual property statutes authorize discovery in litigation involving patents, ${ }^{111}$ copyrights, ${ }^{112}$ trademarks, ${ }^{113}$ utility models, ${ }^{114}$ and design. ${ }^{115}$ Japan's unfair competition statute separately authorizes discovery, based on the discovery process set out in the Patent Act. ${ }^{116}$ Japan's statute prohibiting false advertising imposes separate requirements for advertisers to produce documents supporting claims made in their advertisements. ${ }^{117}$ The 2019 amendments to Japan's Civil Execution Act authorize separate discovery procedures for creditors seeking to execute a judgment. ${ }^{118}$ And Japan's Non-Contentious Litigation Procedure Act, amended 2020, provides a separate discovery regime for appraisal proceedings and other "non-contentious" actions. ${ }^{119}$

110. Bengoshi-HŌ [Attorney Act], Law No. 205 of 1949, art. 23-2, translated in JAPANESE L. TRANS., http://www.japaneselawtranslation.go.jp/law/detail/? $\mathrm{ft}=2 \& \mathrm{re}=2 \& \mathrm{dn}=1 \& \mathrm{yo}=\% \mathrm{E} 5 \% \mathrm{BC} \%$ $81 \% \mathrm{E} 8 \% \mathrm{AD} \% \mathrm{~B} 7 \% \mathrm{E} 5 \% \mathrm{~A} 3 \% \mathrm{AB} \% \mathrm{E} 6 \% \mathrm{~B} 3 \% 95 \& \mathrm{x}=0 \& \mathrm{y}=0 \& \mathrm{ia}=03 \& \mathrm{ja}=04 \& \mathrm{ph}=\& \mathrm{ky}=\& \mathrm{page}=1$ [https://perma.cc/2AD9-HJZL].

111. TOKKYO-HŌ [Patent Act], Law No. 121 of 1959, art. 105, translated in JAPANESE LAW TRANSLATION, http://www.japaneselawtranslation.go.jp/law $/$ detail $/ ? \mathrm{ft}=2 \& \mathrm{re}=2 \& \mathrm{dn}=1 \& \mathrm{yo}=\%$ $\mathrm{E} 7 \% 89 \% \mathrm{~B} 9 \% \mathrm{E} 8 \% \mathrm{~A} 8 \% \mathrm{~B} 1 \% \mathrm{E} 6 \% \mathrm{~B} 3 \% 95 \& \mathrm{x}=0 \& \mathrm{y}=0 \& \mathrm{ia}=03 \& \mathrm{ja}=04 \& \mathrm{ph}=\& \mathrm{ky}=\& \mathrm{page}=1$ [https://perma.cc/VHK9-KVVY].

112. Chosakukenhō [Copyright Act], Law No. 48 of 1970, art. 114-3 (applying the Patent Act discovery process), translated in JAPANESE L. TRANS., http://www.japaneselawtranslation.go. $\mathrm{jp} /$ law $/$ detail $/ ? \mathrm{ft}=2 \& \mathrm{re}=2 \& \mathrm{dn}=1 \& \mathrm{yo}=\mathrm{Copyright}+\mathrm{act} \& \mathrm{x}=0 \& \mathrm{y}=0 \& \mathrm{ia}=03 \& \mathrm{ja}=04 \& \mathrm{ph}=\& \mathrm{ky}=\& \mathrm{pa}$ $\mathrm{ge}=1[\mathrm{https}: / /$ perma.cc/E8NM-BR4S].

113. SHŌHYŌ-HŌ [Trademark Act], Law No. 121 of 1959, art. 39 (applying the Patent Act discovery process), translated in JAPANESE L. TRANS., http:/www.japaneselawtranslation.go.jp/ law/detail/?ft $=2 \& \mathrm{re}=2 \& \mathrm{dn}=1 \& \mathrm{yo}=$ trademark + act $\& \mathrm{x}=0 \& \mathrm{y}=0 \& \mathrm{ia}=03 \& \mathrm{ja}=04 \& \mathrm{ph}=\& \mathrm{ky}=\& \mathrm{page}=1$ [https://perma.cc/LV4P-8UQ3].

114. JitSUYō Shin'AN-HŌ [Utility Model Act], Law No. 123 of 1959, art. 41 (applying the Patent Act discovery process), translated in JAPANESE L. TRANS., http://www.japaneselawtranslat ion.go.jp/law/detail/?ft $=2 \& \mathrm{re}=2 \& \mathrm{dn}=1 \& \mathrm{yo}=$ utility + model + act $\& \mathrm{x}=0 \& \mathrm{y}=0 \& \mathrm{ia}=03 \& \mathrm{ja}=04 \& \mathrm{ph}=$ $\& \mathrm{ky}=\&$ page $=1[\mathrm{https}: / /$ perma.cc/4N9L-HP2W].

115. ISHŌ-HŌ [Design Act], Law No. 125 of 1959, art. 41 (applying the Patent Act discovery process), translated in JAPANESE L. TRANS., http://www.japaneselawtranslation.go.jp/law/detail/ $? \mathrm{ft}=2 \& \mathrm{re}=02 \& \mathrm{dn}=1 \& \mathrm{yo}=$ Design + Act $\& \mathrm{x}=52 \& \mathrm{y}=7 \& \mathrm{ia}=03 \& \mathrm{ja}=04 \& \mathrm{ph}=\& \mathrm{ky}=\& \mathrm{page}=2$ [https://perma.cc/8FPF-24HZ].

116. Fusei Kyōsō BōSHI-HŌ [Unfair Competition Prevention Act], Law No. 47 of 1993, art. 7 (applying the Patent Act discovery process), translated in JAPANESE L. TRANS., http://www. japaneselawtranslation.go.jp/law/detail/?ft $=2 \& \mathrm{re}=2 \& \mathrm{dn}=1 \& \mathrm{yo}=$ Unfair + Competition + Preventio $\mathrm{n}+$ Act $\& \mathrm{x}=0 \& \mathrm{y}=0 \& \mathrm{ia}=03 \& \mathrm{ja}=04 \& \mathrm{ph}=\& \mathrm{ky}=\& \mathrm{page}=1$ [https:/perma.cc/H3W8-9DA2].

117. Yoshiki Takahashi, Kōkoku Shinsa No OK Rainu, Bus. L. J. 90 (Lexis Japan June 2010).

118. Min. of Justice, Minji Shikkō-Hō Oyobi Kokusai-Tekina Ko No Dasshu No MinjiJō No Sokumen Ni Kansuru Jōyaku No Jisshi Ni Kansuru Hōritsu No Ichibu O Kaisei Suru HŌRITSU NO GAIYŌ, http://www.moj.go.jp/content/001293817.pdf [https://perma.cc/UB6P-X5J3].

119. Hishou Jiken Tetsuzuki Hou [Non-Contentious Litigation Procedure Act], Law No. 51 
This section of the Article provides an overview of the primary methods for obtaining written discovery found in the Code of Civil Procedure and the Attorney Act. It saves for another day examination of witnesses and discussion of the less frequently used discovery devices, including the interrogatory-type requests, expert reports, inspections, and the discovery available in specific types of litigation. ${ }^{120}$

\section{A. Petition to Preserve Evidence}

The traditional means to preserve and discover evidence prior to filing the complaint is to petition the court for an order to preserve evidence (shöko hozen meirei). Attorneys characterize this as one of the most important discovery devices. ${ }^{121}$ Article 234 provides a court with authority to issue such an order "[i]f the court finds circumstances to be such that, unless the examination of evidence is conducted in advance, it will be difficult to use the evidence (shōko wo shiyo suru koto ga konnan to naru jijō)."

Courts define "difficult" on a case-by-case basis. An Osaka High Court decision found the risk of undue influence changing a witness's testimony did not constitute circumstances requiring immediate examination of the witness. ${ }^{123}$ In contrast, courts have found the expiration of a five-year document retention period for medical records warranted a preservation order. ${ }^{124}$ Some courts have found an abstract risk of spoliation insufficient to issue a preservation order,

of 2011 (as amended 2020), Hourei teikyou de-ta shisutemu [Hourei DB], https:/elaws.egov.go.jp/document?lawid $=423 \mathrm{AC} 0000000051$. This act incorporates by reference portions of Japan's Code of Civil Procedure, id. at art. 53. For discussion in English of the non-contentious litigation, see Alan K. Koh, Appraising Japan's Appraisal Remedy, 62 Aм. J. CoмP. L 417, $427-$ 429, 448-449 (2014).

120. 2018 Supreme Court statistics show that experts were used in $0.5 \%$ and site or object inspections in $0.1 \%$ of all civil cases filed in the district courts. [2-1-1] JIKEN SHURUI BETSU JIKEN Joukyou (Minji Isshin/Gyousei Isshin/Kasai Jinji) (1) (2018 Final Version), http://www.courts.go.jp/vcms_lf/hokoku_08_siryou2.pdf [https://perma.cc/E36H-FZRL]. Practitioners report that the interrogatory-type requests are rarely used. Nichibenren Symposium Report, supra note 73 , at 30.

121. Attorney interviews, supra note 27.

122. Minjı SoshōHō [Minsohō] [C.Civ.Pro.] Law No. 109 of 1996, art. 234, translated in JAPANESE L. TRANS., http://www.japaneselawtranslation.go.jp/law/detail/?printID $=\& \mathrm{ft}=2 \& \mathrm{re}=$ $2 \& \mathrm{dn}=1 \&$ yо $=\% \mathrm{E} 6 \% \mathrm{~B} 0 \% 91 \% \mathrm{E} 4 \% \mathrm{BA} \% 8 \mathrm{~B} \% \mathrm{E} 8 \% \mathrm{~A} 8 \% \mathrm{~B} 4 \% \mathrm{E} 8 \% \mathrm{~A} 8 \% 9 \mathrm{~F} \% \mathrm{E} 6 \% \mathrm{~B} 3 \% 95 \& \mathrm{x}=48$ $\& \mathrm{y}=10 \& \mathrm{ia}=03 \& \mathrm{ph}=\& \mathrm{ky}=\&$ page $=1 \& \mathrm{vm}=02$ [https://perma.cc/A6TA-6WDU].

123. Osaka Kōtō Saibansho [Osaka High Ct.] Mar. 6, 1963, Sho 38 (ra) no. 24, 147 HANReI TAIMUZU [HANTA] 106.

124. Tōkyō Kōtō Saibansho [Tōkyō High Ct.] Dec. 24, 1981, Sho 56 (ra) no. 722, 464 HANReI TAIMUZU [HANTA] 99. Some courts have even found a lack of knowledge about the applicable document retention policy sufficient for the issuance of an order for preservation. Osaka Kōtō Saibansho [Osaka High Ct.] Nov. 19, 1958, Sho 33 (ra) no. 182, 9 [GEMIN] (11) 2275 (approving a petition to preserve evidence of public documents). 
requiring objective proof to support the inference of a risk of destruction. ${ }^{125}$ Others have found evidence that a doctor refused patient requests for an explanation, or a prior history of spoliation, or inconsistencies in an explanation regarding document retention constituted sufficient risk to order preservation of medical records. ${ }^{126}$ Practitioners confirm what the judicial decisions suggest: the proof required to obtain a preservation order depends on the judge. ${ }^{127}$

The code does not explicitly require proof of the necessity of discovery; however, courts find such proof implicitly required. ${ }^{128}$ They have split on the degree of proof. Some courts have denied petitions for a preservation order where the petitioner failed to explain the need for the evidence. ${ }^{129}$ Other courts have suggested that the importance of the evidence should not be weighed, at this early stage, in a procedure seeking to preserve the evidence. ${ }^{130}$

A party may petition the court for a preservation order either prior to filing suit or after, but before the court begins hearing evidence. ${ }^{131}$ After suit is filed, courts may also issue a preservation order sua sponte. ${ }^{132}$ Courts generally hold a hearing to determine whether to issue the order, providing notice to the proposed recipient, and omitting such notice only under exigent circumstances such as the imminent death of a witness. ${ }^{133}$ The court may also conduct an in camera review of documents to determine whether to issue the order. ${ }^{134}$ In other words, the court can inspect documents to determine whether an inspection is appropriate, and, if it is, then complete the inspection and make copies of the documents or otherwise record the materials. ${ }^{135}$

There is no direct appeal if a court grants a petition to preserve evidence. ${ }^{136}$

125. Hiroshima Chihō Saibansho [Hiroshima Dist. Ct.] Nov. 21, 1986, Sho 51 (so) no. 11, HANREI TAIMUZU [HANTA] 221.

126. Id.

127. Attorney interviews, supra note 27.

128. Sendai Kōtō Saibansho [Sendai High Ct.] Nov. 18, 1988, Sho 63 (ra) no. 65, 1296 HANREI JiHō [HANJI] 75.

129. Id.

130. Tōkyō Kōtō Saibansho [Tōkyō High Ct.] June 30, 1976, Sho (ra) no. 421, 829 HANREI JIHŌ [HANJI 53.

131. Takaomi Takizawa, Shōko no Shūshū/Hozensaku-Shōkō Hozen (1), Bus. L.J. 102 (Lexis Japan Mar. 2016).

132. Minjı SoshōHō [Minsohō] [C.Civ.Pro.] Law No. 109 of 1996, art. 237, translated in JAPANESE L. TRANS., http://www.japaneselawtranslation.go.jp/law/detail/?printID $=\& \mathrm{ft}=2 \& \mathrm{re}=2 \&$ $\mathrm{dn}=1 \& \mathrm{yo}=\% \mathrm{E} 6 \% \mathrm{~B} 0 \% 91 \% \mathrm{E} 4 \% \mathrm{BA} \% 8 \mathrm{~B} \% \mathrm{E} 8 \% \mathrm{~A} 8 \% \mathrm{~B} 4 \% \mathrm{E} 8 \% \mathrm{~A} 8 \% 9 \mathrm{~F} \% \mathrm{E} 6 \% \mathrm{~B} 3 \% 95 \& \mathrm{x}=48 \& \mathrm{y}=$ $10 \& \mathrm{ia}=03 \& \mathrm{ph}=\& \mathrm{ky}=\& \mathrm{page}=1 \& \mathrm{vm}=02$ [https://perma.cc/A6TA-6WDU].

133. Id. art. 240; Takaomi Takizawa, Shōko no Shūshū/Hozensaku-Shōkō Hozen (2), Bus. L. J. 104 (Lexis Japan Apr. 2016).

134. Minsohō (C. Civ. Pro.) arts. 232 (1), 223 (6).

135. Munetaka Marumichi, Shōko Hozen ni tai suru Aitekata no Jitsumu Taiyō, Bus. L. J. 50, 55 (Lexis Japan Dec. 2015).

136. The language of the Code does permit the direct appeal of a denial of a petition to preserve. Takizawa, Shōko Hozen (1), supra note 131, at 103. 
If the court issues the order, it conducts the discovery. ${ }^{137}$ How it does so, however, depends on the type of evidence. Courts may issue orders for inspection, to produce documents, or call witnesses. ${ }^{138}$ If the order seeks to preserve witness testimony, the court calls and the judge examines the witness. ${ }^{139}$ If the order seeks to preserve documents, the process depends on the risk of spoliation. ${ }^{140}$ The court will either command the possessor of the documents to produce the same or arrange for on-site inspection. ${ }^{141}$

With banks and institutions deemed less likely to spoliate, orders to produce documents are common. ${ }^{142}$ In other cases, following entry of an order to preserve, a clerk of the court will typically provide personal notice to the recipient, ${ }^{143}$ and, often within the hour, judges, court clerks, photographers or videographers, and attorneys arrive to inspect the evidence. ${ }^{144}$ Upon arrival, judges request the voluntary cooperation of the recipient of the order, often suggesting cooperation now dispels allegations of spoliation later. ${ }^{145}$ If the recipient refuses to cooperate, the judge may issue, on site, an Order for the Presentation of Inspection Materials (kenshobutsu teiji meirei). ${ }^{146}$

During the inspection, judges (typically mitokurei or associate judges with less than 5 years of experience) will review the documents and dictate a report to the clerk. ${ }^{147}$ After returning to the court, the clerk will prepare the inspection report for the judge's review and signature. ${ }^{148}$ If the recipient of the order objects, the courts have no power to compel the inspection. ${ }^{149}$ In some cases, courts have rescinded an order for inspection, noting in the record that it had no authority to compel the inspection and the recipient's refusal to cooperate created an ongoing impediment to discovery of the evidence. ${ }^{150}$ Practitioners, however, warn of the risk of refusal. ${ }^{151}$ If the recipient becomes a party to litigation, the requesting party may petition the court to enter an adverse inference based on the recipient's

137. Minsohō (C. Civ. Pro.) art. 234.

138. Tetsuo Yabuki, Iryō Kikan to Kojin Jōhō (3)_Hōrei ni Mototzuku Kojin De-ta- no Daisan sha Teikyō, 1191 HoKKAIDO IHŌ 167 (Dec. 1, 2017).

139. Id.

140. Attorney interviews, supra note 27.

141. Id.

142. Id.

143. Marumichi, supra note 135, at 52.

144. Id.

145. Id. at 54-55.

146. Id. at 55 .

147. Id. at 52, 54; Attorney interviews, supra note 27.

148. Marumichi, supra note 135, at 54; Minj Soshou Kisoku [Rules of Civil Procedure], Rules of the Sup. Ct. No. 5 of 1996, arts. 66, 78.

149. Osaka Chihō Saibansho [Osaka Dist. Ct.] July 29, 2004, Hei 16 (mo) no. 3868, 1179 HANRei TAimuZu [HANTA] 342.

150. Marumichi, supra note 135 , at 55 .

151. Id. at 55 . 
earlier refusal to comply with the inspection and preservation order. ${ }^{152}$

The code authorizes the court to adopt an adverse inference if a party fails to appear or refuses to testify, produce a document, or present an object for inspection as ordered. ${ }^{153}$ The court may adopt an adverse inference for failure to comply with a preservation order seeking production of this same evidence. ${ }^{154}$ The adverse inference may take one of two forms. A court may deem as true the petitioner's allegations of facts with regard to the documents or things to have been inspected. ${ }^{155}$ In the alternative, if the court finds it is particularly difficult to prove the facts in question via other means, the court may accept as true the petitioner's claims related to the facts. ${ }^{156}$ For nonparties, the court may impose monetary sanctions for noncompliance in amounts up to $¥ 200,000$ (approximately $\$ 2,000) .{ }^{157}$

The code does not specifically define the scope of an order to preserve evidence. Instead, if something is amenable to a petition to produce evidence pursuant to the code sections addressing witnesses, expert opinions, documentary evidence, and inspections, it is subject to an order for preservation of evidence. ${ }^{158}$ As a result, there are three bases to object to the inspection: (i) the recipient does not have the documents; (ii) the documents are stored elsewhere; or (iii) there is no duty, i.e. the documents fall into one of the exceptions to the duty to produce documents. ${ }^{159}$ It is this last objection that raises the most issues. The scope of the preservation order is dictated by the scope of the duty to produce documents, and appeals regarding scope are often appeals regarding the legal bases for production. ${ }^{160}$

Article 241 provides that the expenses associated with the order for

152. Id.

153. Minjı SoshōHō [Minsohō] [C.Civ.Pro.] Law No. 109 of 1996, art. 234, translated in JAPANESE L. TRANS., http://www.japaneselawtranslation.go.jp/law/detail/?printID $=\& \mathrm{ft}=2 \& \mathrm{re}=$ $2 \& \mathrm{dn}=1 \&$ yo $=\% \mathrm{E} 6 \% \mathrm{~B} 0 \% 91 \% \mathrm{E} 4 \% \mathrm{BA} \% 8 \mathrm{~B} \% \mathrm{E} 8 \% \mathrm{~A} 8 \% \mathrm{~B} 4 \% \mathrm{E} 8 \% \mathrm{~A} 8 \% 9 \mathrm{~F} \% \mathrm{E} 6 \% \mathrm{~B} 3 \% 95 \& \mathrm{x}=48$ $\& \mathrm{y}=10 \& \mathrm{ia}=03 \& \mathrm{ph}=\& \mathrm{ky}=\&$ page $=1 \& \mathrm{vm}=02$ [https:/perma.cc/A6TA-6WDU]. The court may, but is not required, to adopt an adverse inference. See Osaka Chihō Saibansho [Osaka Dist. Ct.], Sept. 10, 1971, 274 HANREI TAIMUZU [HANTA] 337 (finding the defendant refused to permit inspection sought by a competitor in patent litigation based on legitimate concerns about disclosure of business and technical secrets, such that it was not appropriate to adopt an assumption based on plaintiff's claims of infringement).

154. Marumichi, supra note 135 , at 55.

155. Minsohō (C. Civ. Pro.) arts. 232 (1), 224 (3); see also Osaka Chihō Saibansho [Osaka Dist. Ct.], Mar. 30, 1994, 878 Hanrei Taimuzu [Hanta] 253.

156. Minsohō (C. Civ. Pro.) arts. 232 (1), 224 (3).

157. Minsohō (C. Civ. Pro.) art. 232 (1), 232 (2). Exchange rates are approximate and based $¥ 100$ to $\$ 1$.

158. Takizawa, Shōko Hozen (1), supra note 131, at 102-3.

159. Id. at 55-56.

160. See, e.g., Osaka Kōtō Saibansho [Osaka High Ct.] Mar. 15, 1978, Sho 52 (ra) no. 476, 295RōDō HANREI [RŌHAN] 46 (requiring the preservation of a company pay ledger, after finding that it constituted a legal relationship document pursuant to what is now Article 220). 
preservation are taxed as court costs. ${ }^{161}$ But the case law is mixed. Some courts have imposed the entire cost of preserving evidence of medical records on the petitioner. ${ }^{162}$ Others have declined to impose even the costs of a videographer used in the preservation of evidence. ${ }^{163}$

\section{B. Judicial Inquiries \& Court-Commissioned Requests for Information or Documents}

Petitions to preserve evidence are an extraordinary remedy. The costs associated with sending judges out to inspect documents or call witnesses to testify even without a lawsuit on file ensure that the procedure is used sparingly. ${ }^{164}$ In contrast, litigants routinely petition the court for different types of assistance. ${ }^{165}$

Litigants seeking production of records routinely petition the court to commission a party to produce documents. ${ }^{166}$ Article 226 provides that "documentary evidence may be offered by petitioning the court to commission the person in possession of the document to send the document." 167

Litigants file a Petition for a Commission to Deliver Documents (bunsho sōfu shokutaku mōshitate) with the court. ${ }^{168}$ Apart from contact information, the petitions typically contain a summary of the events giving rise to the lawsuit, an explanation of the facts to be proven and the need for the commission, and a discussion of any third-party consent or privacy issues. ${ }^{169}$

Because the authorization for the requests falls within the Evidence chapter of the code, courts apply Article 181 to require the petitioner to provide proof of the need to discover the evidence. ${ }^{170}$ At the same time, the proof required is less

161. Minji SoshōHō [ Minsohō] [C.Civ.Pro.] Law No. 109 of 1996, art. 241.

162. Tōkyō Chihō Saibansho [Tōkyō Dist. Ct.] Sept. 1, 2006, Hei 16 (wa) no. 2353, 1257 HANREI TAIMUZU [HANTA] 196.

163. Nagoya Chihō Saibansho [Nagoya Dist. Ct.] July 4, 2007, Hei 16 (wa) no. 4974, 1299 HANREI TAIMUZU [HANTA] 247.

164. See infra Part IV.A.

165. Tōkyō Dist. Ct. Civ. Sec. Prac. Committee, Minji Soshō ni Okeru Shōko Shūshū Tetsuzuki-Bunsho Sōfu Shokutaku, Bunsho Teishutsu Meirei wo Chūshin Ni, 8 LIBRA (No. 10) 2 (Oct. 2008).

166. Id. at 2-3; Nichibenren Symposium Report, supra note 73, at 10.

167. Minsohō (C. Civ. Pro.) art. 226. This Article goes on to provide an exception: “ . . . this does not apply if a party may request the issuance of an authenticated copy or transcript of the document pursuant to law or regulation." In other words, if the requesting party can obtain the document on its own accord, i.e., without intervention of the court, it is obligated to do so. Id.

168. Tōkyō Dist. Ct. Civil Section Practice Committee, supra note 165, at 2.

169. Id. at 3-4.

170. Nichibenren Symposium Report, supra note 73, at 10; Minsohō (C. CIV. Pro.) art. 181. Article 181 states: "The court is not required to examine evidence offered by a party which the court considers to be unnecessary. (2) If there is any obstacle to the examination of evidence which will be present for an uncertain duration, the court may choose not to conduct an examination of 
than that required for an order to preserve evidence or produce documents. ${ }^{171}$ Similarly, the more onerous procedural rules for the court to issue a preservation or production order, e.g., authorizing hearings and appeals, do not apply. ${ }^{172}$ Courts, as a result, more readily issue these commissions. ${ }^{173}$

If the court determines that the requested documents are necessary to the factfinding process, it commissions production of the same. ${ }^{174}$ The commission is sent by the clerk of court, not the requesting attorney, to the party and identifies the documents to be produced. The commission explains the need for the documents, and even includes postage to send the documents to the court. ${ }^{175}$ If the party complies with the request and sends the documents, they are not automatically entered into evidence. ${ }^{176}$ Rather, a clerk notifies the requesting party, and, after reviewing the documents, the requesting party submits relevant portions to the court, along with an explanation of the evidence (shokko setsumeisho), for consideration. ${ }^{177}$

When the court "commissions" a person or entity to send document(s) to the court, it is not ordering the same. ${ }^{178}$ The commission is a voluntary request, ${ }^{179}$ with the courts relying on the trust the public places in the courts to obtain production. ${ }^{180}$

Courts have held that Article 226 imposes on recipients a "social responsibility" (shakai teki sekimu) to respond to the commission, such that, "absent special circumstances," it will entertain no claim by a third party against a respondent for breach of privacy in producing the requested information. ${ }^{181}$ Separately, the Nichibenren has reprimanded attorneys who have attempted to discourage recipients of court-commissioned requests for information from responding. ${ }^{182}$ But if the recipient of the commission refuses to respond, the code

evidence." Id.

171. Kenchiro Tsuda, Tōkyō Bar Ass'n, Nichibenren, Minji Saiban ni Okeru Jōhō/Shōko Shūshū Hōhō no Kakuritsu ni Mukete, Shinpojium Paneru Deisukashion at 27 (Sept. 4, 2019), https://www.nichibenren.or.jp/library/ja/publication/booklet/data/symposium.pdf [https://perma.cc/8LJP-FFPB] [hereinafter Nichibenren Panel Discussion].

172. $I d$.

173. Id.

174. Tōkyō Dist. Ct. Civil Section Practice Committee, supra note 165, at 3.

175. Id.

176. Id., at 2-3; Nichibenren Symposium Report, supra note 73, at 10.

177. Tōkyō Dist. Ct. Civil Section Practice Committee, supra note 165, at 10. As a general rule, the court will seek production of original records; however, practitioners suggest that copies are often produced and third parties will often contact the petitioner directly for reimbursement of copying charges. Id.

178. Tōkyō Dist. Ct. Civil Section Practice Committee, supra note 165, at 4.

179. Nichibenren Panel Discussion, supra note 171, at 27.

180. Tōkyō Dist. Ct. Civil Section Practice Committee, supra note 165, at 4.

181. Osaka Kōtō Saibansho [Osaka High Ct.] Feb. 20, 2007, Hei 18 (ne) no. 2860, 1263

HanRei taimuzu [HANTA] 301; Nichibenren Symposium Report, supra note 73, at 11.

182. Heisei 29.5.25 Keikoku Shobun, Shobun no Riyū to Yōshi, JiYū to SEIGI 71 (Aug. 2017). 
provides no penalties, and there is no right of appeal. ${ }^{183}$ If the recipient refuses to respond to the commission, the courts ask again: they request additional information from the petitioner regarding purpose and need, and they convey the same to the respondent. ${ }^{184}$ The courts, in effect, seek to broker a response. ${ }^{185}$ They encourage recipients to respond. ${ }^{186}$

If these repeated requests are met with refusal, litigants are left to petition the court to enter an order for production of documents, for which there are sanctions for refusal. ${ }^{187}$ Applying to the court to commission voluntary production of the documents is considered a less confrontational, preliminary step, to seeking a court order. ${ }^{188}$

The Code of Civil Procedure also authorizes courts to commission production of information (chōsa shokutaku), as opposed to documents. Article 186 authorizes the courts to "commission a government agency or public office . . . chamber of commerce, exchange, or any other organization to conduct the necessary examinations" and provide information regarding a matter. ${ }^{189}$

Article 186 offers a commonly used means to seek third-party production of information. Examples include litigants requesting the court commission a financial institution to investigate and report on the assets held by a spouse in a dissolution of marriage case or commission a medical institution to report on a patient's condition in a competency hearing. ${ }^{190}$ The Supreme Court has held that, if the court affords the opposing party an opportunity to respond, the commissioning court may consider the report as evidence and base its decision on the same. ${ }^{191}$ Like the commission to produce documents, recipients of these

183. See Minji Soshōhō [ Minsohō] [C.Civ.Pro.] Law No. 109 of 1996, arts. 179-241, translated in JAPANESE L. TRANS., http:/www.japaneselawtranslation.go.jp/law/detail/?printID= $\& \mathrm{ft}=2 \& \mathrm{re}=2 \& \mathrm{dn}=1 \& \mathrm{yo}=\% \mathrm{E} 6 \% \mathrm{~B} 0 \% 91 \% \mathrm{E} 4 \% \mathrm{BA} \% 8 \mathrm{~B} \% \mathrm{E} 8 \% \mathrm{~A} 8 \% \mathrm{~B} 4 \% \mathrm{E} 8 \% \mathrm{~A} 8 \% 9 \mathrm{~F} \% \mathrm{E} 6 \% \mathrm{~B} 3$ $\% 95 \& \mathrm{x}=48 \& \mathrm{y}=10 \& \mathrm{ia}=03 \& \mathrm{ph}=\& \mathrm{ky}=\& \mathrm{page}=1 \& \mathrm{vm}=02 \quad$ [https $: /$ perma.cc $/$ A6TA-6WDU]; Nichibenren Symposium Report, supra note 73, at 11.

184. Nichibenren Panel Discussion, note 171, at 28 (referring to comments made by former Nagoya High Court Justice Masato Kadoguchi).

185. Id.

186. Nichibenren Symposium, Bunsho Teishutsu Meirei no Genjō to Kadai at 2-3 (Sept. 4, 2018), https://www.nichibenren.or.jp/library/ja/publication/booklet/data/symposium.pdf [https:// perma.cc/HTC2-CCE7].

187. Yabuki, supra note 138 , at 16.

188. Id.

189. Minjı SoshōHō [Minsohō] [C.Civ.Pro.] Law No. 109 of 1996, art. 186, translated in JAPANESE L. TRANS., http://www.japaneselawtranslation.go.jp/law/detail/?printID $=\& \mathrm{ft}=2 \& \mathrm{re}=2 \&$ $\mathrm{dn}=1 \& \mathrm{yo}=\% \mathrm{E} 6 \% \mathrm{~B} 0 \% 91 \% \mathrm{E} 4 \% \mathrm{BA} \% 8 \mathrm{~B} \% \mathrm{E} 8 \% \mathrm{~A} 8 \% \mathrm{~B} 4 \% \mathrm{E} 8 \% \mathrm{~A} 8 \% 9 \mathrm{~F} \% \mathrm{E} 6 \% \mathrm{~B} 3 \% 95 \& \mathrm{x}=48 \& \mathrm{y}=$ 10\&ia $=03 \& \mathrm{ph}=\& \mathrm{ky}=\&$ page $=1 \& \mathrm{vm}=02$ [https://perma.cc/A6TA-6WDU].

190. See, e.g., Kamioka Hōritsu Jimusho, Tsuma no Yokin ga Wakarnai (Chōsa Shokutaku ni tsuite) [https://perma.cc/YK2D-LZHB]; Yabuki, supra note 138, at 16.

191. Saikō Saibansho [Sup. Ct.] Mar. 26, 1970, Sho 44 (o) no. 1156, 248 Hanrei TAIMUZU [HANTA] 114. 
commissions owe a public duty to provide information, ${ }^{192}$ but, once again, there are no penalties for refusing to respond. Litigants are left to follow such refusal by calling individuals to testify or seeking a court-appointed expert to investigate and report on the matter. ${ }^{193}$

Courts may issue the commission sua sponte, but a former judge suggests the courts consider this exercise of authority as interfering with the principle of party autonomy and use the power rarely and only as a supplement to the evidence introduced by the parties. ${ }^{194}$ This tension between permissible judicial inquiry and impermissible judicial interference is present in another commonly used means for discovering information in civil litigation in Japan: the exercise of the judge's authority to examine evidence. ${ }^{195}$

The Code of Civil Procedure permits judges to examine evidence or witnesses and designate evidence sua sponte. ${ }^{196}$ The code also authorizes a judge to request clarification of contested legal or factual issues: Article 149 states, " $[t]$ he presiding judge, on a date for oral arguments or on any other date may ask questions of a party or call for a party to give proof with regard to a factual or legal matter, in order to clarify a matter that is related to the litigation." ${ }^{197}$ A party may, in turn, "request the presiding judge to ask any necessary questions."198 If a judge inquires at a time other than during oral arguments regarding a matter that "could materially change the allegations or evidence," the judge must notify the opposing party of the inquiry. ${ }^{199}$

The code authorizes the judge to "encourage" (unagasu) production of proof necessary to clarify factual and legal contentions. ${ }^{200}$ Standard doctrine interprets this section as enabling judges to correct the errors and omissions arising from the adversary system and enable resolution of the dispute based on the facts: where the parties' documentary submissions are inadequate or unclear, the court has an obligation to take steps to clarify the record. ${ }^{201}$ At the same time, practitioners actively use this statute to discover relevant evidence, not just clarify the issues. ${ }^{202}$

192. Yabuki, supra note 138, at 16.

193. Id.

194. Takaomi Takizawa, Shōko Shūshū/Hozensaku - Chōsa Shōtaku, Bus. L. J. 86 (Lexis Japan May 2016).

195. Minjı SoshōHō [Minsohō] [C.Civ.Pro.] Law No. 109 of 1996, art. 149, translated in JAPANESE L. TRANS., http://www.japaneselawtranslation.go.jp/law/detail/?printID=\&ft=2\&re=2\& $\mathrm{dn}=1 \& \mathrm{yo}=\% \mathrm{E} 6 \% \mathrm{~B} 0 \% 91 \% \mathrm{E} 4 \% \mathrm{BA} \% 8 \mathrm{~B} \% \mathrm{E} 8 \% \mathrm{~A} 8 \% \mathrm{~B} 4 \% \mathrm{E} 8 \% \mathrm{~A} 8 \% 9 \mathrm{~F} \% \mathrm{E} 6 \% \mathrm{~B} 3 \% 95 \& \mathrm{x}=48 \& \mathrm{y}=$ 10\&ia=03\&ph=\&ky=\&page=1\&vm=02 [https://perma.cc/A6TA-6WDU]; Yumiko Saito, Sekkyoku teki na Shakumei to Shakumeiken Kōshi no Genkai ni tsuite, 47 DAIGAKUIN KENNKYū NENPō 243 (Feb. 2018).

196. Minsohō (C. Civ. Pro.) arts. 149, 190-194, 207.

197. Id. art. 149(1).

198. Id. art. 149(2).

199. Id. art. 149(4).

200. Saito, supra note 195, at 244.

201. Id.

202. Attorney interviews, supra note 27. 
And scholars have long argued this statute should be used to level the playing field and place the parties in an equal position to collect relevant information. ${ }^{203}$

Practitioners do so by requesting, during oral arguments, that the court seek production of specific information or documents. ${ }^{204}$ They also file written petitions with the court requesting the court exercise its authority to clarify facts relating to certain contentions ( $k y \bar{u}$ shakumei moshitate). ${ }^{205}$ For example, in a suit regarding termination of a lease, a petition may state that the plaintiff seeks termination of the lease without identifying the time or reason for its termination and defendant would like for this to be made clear. ${ }^{206}$ In a breach of contract dispute, the petition may request the court call a third party witness to testify regarding contract formation. ${ }^{207}$ The court may then issue an order for clarification, ordering a party to appear or submit a statement, produce documents, or commission an inspection or examination. ${ }^{208}$

Despite the narrow language of the statute, the Supreme Court has acknowledged its purpose to both clarify and discover relevant information:

The system of judicial inquiry was established with the purpose of correcting the irrationalities of the formal application of oral argument, to clarify the matters relating to the litigation, and, as much as possible, to discover the truth of the matter in order to facilitate a just resolution of the dispute. ${ }^{209}$

The courts vary, however, in their willingness to intervene. Some courts actively exercise their authority to inquire, to seek an explanation of the law or facts; some do not. ${ }^{210}$

\section{Bar Association-Mediated Requests for Documents}

When the Attorney Act was adopted in 1951, the Diet debated giving

203. Saito, supra note 195, at 244.

204. Attorney interviews, supra note 27.

205. Id.; see, e.g., Heisei 31 (wa) No. 3465 (Kokka Baishō Seikyū Jiken), https://www. call4.jp/file/pdf/201907/f7acf82e202be774640f05d0c50717fb.pdf; Reiwa Gannen (gyō ke) No. 2, (Chihō Jichi Hō Dai 251 Jō ni Motoduku Torikeshi Jiken), https://www.pref.okinawa.lg.jp/ site/chijiko/henoko/documents/190917kyuusyakumei.pdf.

206. Civil Proceedings Manual Form Collection, Ch. 4, available at https://shop.gyosei. $\mathrm{jp} /$ contents/cs/info/3100518/html/minso0104.html.

207. Id.

208. Minji SoshōHō [Minsohō] [C.Civ.Pro.] Law No. 109 of 1996, art. 151, translated in JAPANESE L. TRANS., http://www.japaneselawtranslation.go.jp/law/detail/?printID $=\& \mathrm{ft}=2 \& \mathrm{re}=2 \&$ $\mathrm{dn}=1 \& \mathrm{yo}=\% \mathrm{E} 6 \% \mathrm{~B} 0 \% 91 \% \mathrm{E} 4 \% \mathrm{BA} \% 8 \mathrm{~B} \% \mathrm{E} 8 \% \mathrm{~A} 8 \% \mathrm{~B} 4 \% \mathrm{E} 8 \% \mathrm{~A} 8 \% 9 \mathrm{~F} \% \mathrm{E} 6 \% \mathrm{~B} 3 \% 95 \& \mathrm{x}=48 \& \mathrm{y}=$ 10\&ia $=03 \& \mathrm{ph}=\& \mathrm{ky}=\&$ page $=1 \& \mathrm{vm}=02$ [https://perma.cc/A6TA-6WDU].

209. Saikō Saibansho [Sup. Ct.] June 11, 1970, Shou 45 (o) no. 52, 24 SAikō SAibansho Minji HanReishū [Minshū] (No. 6) 516.

210. Saito, supra note 195 , at $243-45$. 
attorneys the express authority to investigate facts and gather evidence. ${ }^{211}$ The proposal went nowhere. ${ }^{212}$ Those in favor sought to afford private attorneys the ability to request information from public and private entities, just as prosecutors, the courts, members of the Prosecution Review Board, Public Safety Commission, and immigration authorities do. ${ }^{213}$ Those opposed criticized the measure as placing attorneys on equal footing with prosecutors, without the requirement that they seek a warrant for the discovery intended. ${ }^{214}$ Following intense lobbying by the bar, in 1953, the Diet took a half-step. They adopted a proposal by a member of the House of Representatives, opposed by the Ministry of Justice, to amend the Attorney Act to authorize attorney discovery mediated by local bar associations. ${ }^{215}$

Article 23-2 of the Attorney Act now authorizes an attorney to petition the bar association to which $\mathrm{s} / \mathrm{he}$ belongs to request public or private organizations produce necessary information relating to a matter for which the attorney has agreed to provide legal services (bengoshikai shōkai). ${ }^{216}$ The statute limits the recipients of such requests to organizations, as opposed to private individuals, on the assumption that the former have better record-keeping systems in place. ${ }^{217}$ Courts have, however, extended this language to cover requests to professionals such as judicial scriveners, patent agents, and the like, as well as individual proprietors of hospitals and factories..$^{218}$

Unlike court-commissions, it is not necessary that the request relate to pending litigation; instead, this section has been interpreted to include discovery related to negotiations or requests for legal advice. ${ }^{219}$ Unlike other pre-complaint

211. Joukai Bengoshi Hou 158 (Nihon Bengoshi Rengoukai Chousaishitsu ed., 4th ed. 2007).

212. Id.

213. Masao lihata, ShōKai Seido no Jisshō teki Kenkyū 3 (1984) (citing KeiJ Soshōhō [Keisohō] [C.Crim. Pro.], Law No. 131 of 1948, arts. 197(2), 279; Kensatsu Shinsakai Hō [Prosecution Review Commission Act], Law No. 147 of 1968, art. 26; HaKi Katsudō Bōshi Hō [Subversive Activities Prevention Act], Law No. 240 of 1952, art. 22; and SHutsunYūKoKu Kanri Oyobi Nanmin Nintei Hō [Immigration Control and Refugee Recognition Act], Law No. 319, art. 28.

214. Joukai Bengoshi Hou, supra note 211, at 158.

215. Nichibenren Symposium Report, supra note 73, at 4; JouKai BeNGOSHI Hou, supra note 211, at 158-9; Iihata, supra note 213, at 7.

216. BeNGOSHI-HŌ [Attorney Act], Law No. 205 of 1949, art. 23-2, translated in JAPANESE L. TRANS., http://www.japaneselawtranslation.go.jp/law/detail/?ft $=2 \& \mathrm{re}=2 \& \mathrm{dn}=1 \& y \mathrm{yo}=\% \mathrm{E} 5 \% \mathrm{BC} \%$ $81 \% \mathrm{E} 8 \% \mathrm{AD} \% \mathrm{~B} 7 \% \mathrm{E} 5 \% \mathrm{A3} \% \mathrm{AB} \% \mathrm{E} 6 \% \mathrm{~B} 3 \% 95 \& \mathrm{x}=0 \& \mathrm{y}=0 \& \mathrm{ia}=03 \& \mathrm{ja}=04 \& \mathrm{ph}=\& \mathrm{ky}=\& \mathrm{page}=1$ [https://perma.cc/2AD9-HJZL].

217. Kyoto Chihō Saibansho [Kyoto Dist. Ct.] Jan. 24, 2007, 1238 Hanrei taimuZu [Hanta] 325; Shiro Abe \& Hideto Yamauchi, Bengoshikai Shōkai ni yoru Jōhō/Shiryō no Shutoku, Bus. L. J. 108 (Lexis Japan Dec. 2014).

218. Kyoto Chihō Saibansho, [Kyoto Dist. Ct.] Jan. 24, 2007, 1238 HantA 325.

219. Abe \& Yamauchi, supra note 217, at 108; Nichibenren Symposium Report, supra note 73 , at 4 . 
discovery devices, bar association requests do not require counsel to provide a notice of intent to litigate to the opposing party. ${ }^{220}$ They can be used without notifying a putative opposing party, and there are no time restrictions attached to their use. ${ }^{21}$

Each bar association charges a fee to process the request and maintains its own standards for issuing them. ${ }^{222}$ The Tokyo Bar Association requires an attorney-petitioner to file a petition seeking issuance of the request and charges $¥ 7,350$ (approximately $\$ 73.50$ ) to review the same. ${ }^{223}$ An internal review committee then examines: (a) whether there is a need to protect privacy or trade secrets; (b) the relationship between the litigants and the recipient of the request; (c) the importance of the requested information in relationship to the issues in dispute; and, finally, (d) whether there are other more expedient means to discover the information. ${ }^{224}$

A 2015 survey suggests that local bar associations refuse to issue only five percent of all requests received, but practitioners suggest the actual numbers are significantly higher. ${ }^{225}$ The Attorney Act permits a bar association to refuse any request it finds "inappropriate," 226 and practitioners suggest bar associations decline to issue requests likely to be refused. ${ }^{227}$ Some practitioners suggest the review focuses on form and the language in the request demonstrating need. ${ }^{228}$ Others describe the bar associations employing a substantive balancing test, considering the above factors to determine the need and appropriateness of the request: the more sensitive the information requested, the greater the need for the information required to issue the commission. ${ }^{229}$

Courts have recognized the right to object to bar association requests, and there are numerous decisions attempting to define the parameters of the duty to respond. ${ }^{230}$ As a general principle, courts have imposed a public law duty to respond to a request made by a local bar association. ${ }^{231}$ They have affirmed the validity of requests sent to banks regarding the transaction histories of deceased

220. Nichibenren Symposium Report, supra note 73, at 4; Nichibenren Keynote Report, supra note 70 , at 2 .

221. Nichibenren Symposium Report, supra note 73, at 4; Nichibenren Keynote Report, supra note 70 , at 2 .

222. Nichibenren Panel Discussion, supra note 171, at 28.

223. Id.; Bengoshikai Shoukai Seido, Katsuyō no Pointo, 11 LIBRA (No. 4) 30, 33 (Apr. 2011).

224. Nichibenren Panel Discussion, supra note 171, at 28.

225. Nichibenren Symposium Report, supra note 73, at 5.

226. Id.

227. $I d$. at 5-6.

228. Attorney interviews, supra note 27.

229. Nichibenren Panel Discussion, supra note 171, at 28-9.

230. Takaomi Takizawa, Shōko no Shūshū/Hozensaku—Bengoshikai Shōkai, Bus. L. J. 98 (Lexis Japan Feb. 2016).

231. Nichibenren Symposium Report, supra note 73, at 6. See, e.g., Nagoya Kōtō Saibansho [Nagoya High Ct.] June 30, 2016, Hei 28 (ne) no. 912, 2349 HaNrei JiHō [HANJI] 56. 
clients, account information for clients in bankruptcy, ${ }^{232}$ and requests to fire departments for ambulance reports. ${ }^{233}$

At the same time, the respondent may be subject to a claim for damages if it provides information that violates a third party's rights. ${ }^{234}$ Courts have rejected requests for information made to tax agents, in light of the agent's duty of confidentiality to their clients, ${ }^{235}$ and they have held liable in tort tax agents who have disclosed information in response to a request but in violation of a legally mandated duty to maintain client confidences. ${ }^{236}$

In deciding whether there is a reasonable basis to refuse the request, the courts balance the interest to be protected and the harm arising from the disclosure compared to the harm arising from failure to respond. ${ }^{237}$ As it is the bar association that makes the request, ${ }^{238}$ the courts hold that the duty to respond is owed to the bar. ${ }^{239}$ As a result, neither the requesting attorney nor the client has the authority to seek damages for an organization's wrongful refusal to respond to the request. ${ }^{240}$ Practitioners report bar associations demanding damages for improper refusal to respond to inquiries and a growing body of case law recognizing potential liability for failure to respond but not yet imposing any. ${ }^{241}$ At this point, as with the court-commissions, there are no sanctions for failure to respond.

\section{Petition for Order of Production of Documents}

Absent cooperation, or a voluntary response to a court-commission or bar association-mediated request, litigants must petition the court to order production of documents.

Article 219 states that "[d]ocumentary evidence shall be offered through the submission of a document or a request for the court to order the person in possession of a document to submit that document." ${ }^{242}$ The former permits a

232. Tōkyō Kōtō Saibansho [Tōkyō High Ct.] Aug. 3, 2011, Hei 22 (ne) no. 6527, 1935 KIN'YŪ HŌ MU JIJō [KINHŌ] 118; Osaka Kōtō Saibansho [Osaka High Ct.] Jan. 30, 2007, Hei 18 (ne) no. 779, 1263 KIN'YŪ SHŌJI HANREI [KINHAN] 25.

233. Nagoya Kōtō Saibansho [Nagoya High Ct.] July 8, 2011, Hei 23 (gyou-ko) nos. 22, 40, 1988 KIN'YŪ HŌ MU JIJŌ [KINHŌ] 135.

234. Takizawa, Bengoshikai Shōkai, supra note 230, at 99; Abe \& Yamauchi, supra note 217, at 109; Nichibenren Symposium Report, supra note 73, at 6.

235. Osaka Kōtō Saibansho [Osaka High Ct.] Aug. 28, 2014, Hei 25 (ne) no. 3473, 1409 HANREI TAIMUZU [HANTA] 241.

236. Id.

237. $I d$.

238. Takizawa, Bengoshikai Shōkai, supra note 230, at 99.

239. Tōkyō Kōtō Saibansho [Tōkyō High Ct.] Apr. 11, 2013, Hei 25 (ne) no. 1019, 1988 JUNKAN KIN'YŪ HŌMU JIJŌ [Kinhō] 114.

240. Id.

241. Takizawa, Bengoshikai Shōkai, supra note 230, at 98, 102.

242. Mını SoshōHō [Minsohō] [C.Civ.Pro.] Law No. 109 of 1996, art. 219, translated in 
litigant in possession to submit the document in court for consideration as evidence, either during oral arguments or in preparatory filings. ${ }^{243}$ The latter section authorizes the court to issue "orders for the production of documents." 244

The order to produce documents is not considered a method to discover evidence but rather a means to produce evidence to the court. ${ }^{245}$ The organization of the code makes this clear. ${ }^{246}$ Article 219 is found in the part of the code addressing offering and examining documentary evidence in the district court. ${ }^{247}$ Yet, while the procedure is not intended as a means to discover relevant information, ${ }^{248}$ it is used as such. Japanese scholars have suggested it is the "functional equivalent" of a subpoena duces tecum. ${ }^{249}$

\section{Scope of the Production}

There are two basic requirements for the court to issue the order: the requesting party must demonstrate: (1) evidentiary necessity for the production of the document(s); and that (2) the possessor of the document(s) owes a duty to produce the same. ${ }^{250}$

As with a petition requesting the court to commission production of documents, the first requirement stems from Article 181. ${ }^{251}$ According to the courts, a petitioner seeking an order requiring production of a document must first establish the "need to discover evidence" (shōko shirabe no hitsuyōsei). ${ }^{252}$ The parties routinely litigate this issue, ${ }^{253}$ and the courts routinely deny petitions

JAPANESE L. TRANS., http://www.japaneselawtranslation.go.jp/law/detail/?printID=\&ft=2\&re=2\& $\mathrm{dn}=1 \& \mathrm{yo}=\% \mathrm{E} 6 \% \mathrm{~B} 0 \% 91 \% \mathrm{E} 4 \% \mathrm{BA} \% 8 \mathrm{~B} \% \mathrm{E} 8 \% \mathrm{~A} 8 \% \mathrm{~B} 4 \% \mathrm{E} 8 \% \mathrm{~A} 8 \% 9 \mathrm{~F} \% \mathrm{E} 6 \% \mathrm{~B} 3 \% 95 \& \mathrm{x}=48 \& \mathrm{y}=$ $10 \& \mathrm{ia}=03 \& \mathrm{ph}=\& \mathrm{ky}=\& \mathrm{page}=1 \& \mathrm{vm}=02$ [https://perma.cc/A6TA-6WDU].

243. Saikō Saibansho [Sup. Ct.] Sept. 21, 1962, Sho 3 (o) no. 71, 16 DAISHIN'IN MINJI HANREISHŪ [MINSHū] (no. 9) 2052.

244. Satoshi Aoki, Bunsho Teishutsu Meirei, 460 Hougaku Kyoushitsu 115 (Jan. 2019).

245. Nichibenren Symposium Report, supra note 73, at 3.

246. Nichibenren Keynote Report, supra note 70, at 7.

247. Minsohō (C. Civ. Pro.) arts. 179-231.

248. Nichibenren Keynote Report, supra note 70, at 5.

249. Kojima, supra note 28, at 702.

250. Aoki, supra note 244, at 115.

251. Minsohō (C. Civ. Pro.) art. 181.

252. Nichibenren Symposium Report, supra note 73, at 3. See, e.g., Tōkyō Chisai [Tōkyō Dist. Ct.] 1419 HANREi TAIMUZU [HANTA] 367 (requiring proof of a "reasonable suspicion" of a theft of trade secrets before recognizing the "necessity" of discovery or related evidence).

253. See, e.g., Saikō Saibansho [Sup. Ct.] July 22, 2005, Hei 17 (kyo) no. 4, 1191 HANREI TAimuZu [Hanta] 230; Chiteki Zaisan Kōtō Saibansho [Intellectual Property Ct.] Mar. 28 2016, Hei 27 (ne) 10029; Tōkyō Kōtō Saibansho [Tōkyō High Ct.] Feb. 26, 2010, Hei 21 (ra) no. 1912, 1331 Hanrei taimuzu [Hanta] 268; Chiteki Zaisan Kōtō Saibansho [Intellectual Property High Ct.] Sept. 11., 2014, Hei 26 (ne) no. 10042; Fukuoka Kōtō Saibansho [Fukuoka High Ct.] Mar. 28 2011, Hei 22 (u) no. 210, 1373 Hanrei TAIMUZu [HANTA] 239; Osaka Chihō Saibansho [Osaka Dist. Ct.] June 15, 2012, Hei 23 (mo) no. 566, 1389 HANRei TAimuZU [HantA] 352; Tōkyō Chihō 
because they find no need for discovery of the evidence in question. ${ }^{254}$ Practitioners note that the courts interpret this provision narrowly. ${ }^{255}$ A former Supreme Court judge has concluded that the functional standard for demonstrating "necessity" in a petition for an order to produce documents is "indispensability" (fukaketsu). ${ }^{256}$ The evidence must be indispensable to the resolution of the case.

The second requirement arises from Article 220. After the 1996 amendments, Article 220 defines the scope of the discovery request and objections. As discussed above, the three categories of documents enumerated under the old code remain. ${ }^{257}$ The code continues to provide litigants with a right to seek production of documents that a party (1) has cited in the litigation; (2) has a right to demand or inspect; or that (3) establish a beneficial or legal relationship. ${ }^{258}$

The 1996 revisions added section (4) imposing a general duty to produce documents, subject to five enumerated exceptions. ${ }^{259}$ The first exception permits the possessor, or a related party, to object to production where the document(s) in question, if disclosed, would create a risk of prosecution, criminal liability, or harm to reputation. ${ }^{260}$

The 2001 amendments added the second ${ }^{261}$ and codifies public servants' duty of confidentiality. ${ }^{262}$ It permits public servants to object to production of documents where they contain confidential information the disclosure of which would harm the public interest or create a risk of significant impediment to completing public work. ${ }^{263}$

The third exception permits enumerated professionals, including doctors and lawyers, who hold documents containing confidential occupational information or technical information to object to production of such documents where disclosure of facts contained therein would cause harm. ${ }^{264}$ It is this section that

Saibansho [Tōkyō Dist. Ct.] Oct. 2, 2009, Hei 21 (ra) no. 3573.

254. Nichibenren Symposium Report, supra note 73, at 3; Nichibenren Keynote Report, supra note 70 , at 5 .

255. Nichibenren Symposium Report, supra note 73, at 3; Nichibenren Keynote Report, supra note 70 , at 5 .

256. Nichibenren Symposium Report, supra note 73, at 8 n.22.

257. Minsohō (C. CIV. Pro.) art. 220(i)-(iii).

258. Id.

259. Id. at art. 220(iv). The Supreme Court provides a slightly different translation from that found on the Ministry of Justice's Japanese Law Translation site. See Saiko Saibansho [Sup. Ct.] Oct. 4, 2017, 2017 (Gyo-Fu) no. 8, 71 Saikō Saibansho minji hanreishū [Minshū] (No. 8) 2.

260. See Minsohō (C. Civ. Pro.) art. 196. Related parties are defined to include spouses; Fourth degree or less blood relations or third degree or less relations by marriage. Takizawa,

Bunsho Teishutsu Meirei (1), supra note 49, at 112.

261. Michikata, supra note 41, at 4.

262. Takizawa, Bunsho Teishutsu Meirei (1) supra note 49, at 112.

263. See Minsohō (C. Civ. Pro.) arts. 191, 197.

264. Id. at art. 220(iv)(c). Prior to the amendments, courts reasoned by analogy to extend the 
gives rise to an attorney's ability to protect certain client confidences.

The fourth exception, the internal use exception, applies more broadly. It permits the holder of "a document prepared exclusively for the use of the person in possession" to object to production of the document. ${ }^{265}$ But there is an exception to the exception, this protection does not apply to business records maintained by national or regional government entities. ${ }^{266}$

Finally, the statute provides that disclosure or nondisclosure of documents used in criminal investigations should be determined by criminal procedure. ${ }^{267}$ As such, disclosure pursuant to this general duty to produce documents is not required. ${ }^{268}$ At the same time, the Supreme Court has held that courts may require disclosure if the documents constitute "legal relationship" documents and the possessor of the documents, usually the prosecutor's office, abuses its discretion in refusing to disclose the same. ${ }^{269}$

In short, after the 1996 amendments, with certain enumerated exceptions, a litigant may petition the court to order a party or non-party to produce any "necessary" document. ${ }^{270}$ But they do not make it easy.

\section{Procedural Issues}

The courts encourage the parties to first seek voluntary production of the documents and actively attempt to negotiate the same. ${ }^{271}$ If that fails, Article 221 sets out the requirements for filing the petition for an order of production. Only litigants may petition for an order to produce documents, and the device is not available prior to the filing of the complaint. ${ }^{272}$ Once suit is filed, a litigant may

protections afforded to witnesses called to testify to those documents containing the same types of information. This section codifies those judicial decisions. Takizawa, Bunsho Teishutsu Meirei (1), supra note 49, at 113.

265. See Minsohō (C. Civ. Pro.) art. 220(iv)(d). See also Saikō Saibansho [Sup. Ct.], Nov. 12, 1999, Hei 11 (kyo) No. 2, 1017 Hanrei taimuzu [Hanta] 102.

266. See Minsohō (C. Civ. Pro.) art. 220(iv)(d).

267. Article 47 of the Code of Criminal Procedure generally prohibits disclosure of litigation documents in criminal cases prior to the start of trial. KeiJi Soshōhō [KeIsohō] [C. CRIM. Pro.] Act No. 131 of 1948, art. 47, translated in JAPANESE L. TRANS., http://www.japaneselawtranslation. go.jp/law/detail/?id=3364\&vm=02\&re=02 [https://perma.cc/9YFJ-EXZ7].

268. Cf. Minsohō (C. Civ. Pro.) art. 220 (iv)(e).

269. Saikō Saibansho [Sup. Ct.] May 25, 2004, Hei 15 (kyo) No. 40, 58 SAIKō SAIBAnsho MINJI HANREISHŪ [Minshū] (No. 5) 1135.

270. Takaomi Takizawa, Shōko no Shūshū/Hozensaku—Bunsho Teishutsu Meirei (2), Bus. L. J. 98, 99 (Lexis Japan Mar. 2017).

271. Nihon Benrishikai [Japanese Federation of Patent Agents], Chisai Soshō ni Okeru Bunsho Teishutsu Meirei ni Kan Suru Chōsa, Kenkyū Oyobi Teigen 18 (Feb. 17, 2015), in https://www. kantei.go.jp/jp/singi/titeki2/tyousakai/kensho_hyoka_kikaku/2016/syori_system/dai5/siryou3.pdf [https://perma.cc/3GE2-7VS2]. See also Osaka Appellate Ct., May 15, 2009, Hei 20 (ra) No. 1051; Attorney interviews, supra note 27.

272. Takizawa, Bunsho Teishutsu Meirei (1), supra note 49, at 107. 
seek production from a party or non-party. ${ }^{273}$

Article 221 requires the petitioner to identify the document(s) requested, by describing in the petition: (i) the title and author, or "indication" (hyōji), of the document; ${ }^{274}$ (ii) the "gist" (shushi) of the document; ${ }^{275}$ (iii) the possessor; (iv) the facts the petitioner expects to prove with the document; (v) and the basis of the respondent's legal obligation to produce the same. ${ }^{276}$ For those documents requested pursuant to Article 220(iv), the general duty to produce, petitioners must also show that the order is necessary to offer evidence for consideration by the court. ${ }^{277}$

Courts have defined "documents" broadly. While the code speaks of "documents," and litigants have challenged requests seeking printouts of electronically stored information, e.g., reports from HR databases, courts have ordered such production finding this information constitutes a "quasidocument." ${ }^{\prime 278}$

The courts have split over the specificity required to identify the document or quasi-document subject to the order. The Supreme Court has recognized categorical requests where the category itself is defined by public ordinance. Where petitioner requested an order for production of "all audit records," the Supreme Court found this sufficient because a public ordinance defined and required preservation of specified audit records. ${ }^{279}$ In other instances, the Supreme Court has rejected claims seeking "any and all" documents. ${ }^{280}$

The lower courts are varied in their response, with some approving requests seeking, e.g., all communications related to financial transactions between litigants or all documentation relating to the suitability of a customer for a particular transaction. ${ }^{281}$ Practitioners are equally divided in their comments:

273. Id.

274. The (i) "indication" generally includes the title of the document; date of creation; author; and similar metadata about the document. Aya Yamada, Minji Soshō Hō Dai Ichi Hen (Sōsoku)—Dai 1 shō (Tsūsoku), InTA-NETTO KonNMENTA-RU (2015).

275. The (ii) "gist" of the document generally describes its contents. The intent of these first two requirements is to allow the court and the respondent to identify the specific document(s) requested. $I d$.

276. Minjı SoshōHō [Minsohō] [C.Civ.Pro.] Law No. 109 of 1996, art. 221, translated in JAPANESE L. TRANS., http://www.japaneselawtranslation.go.jp/law/detail/?printID=\&ft=2\&re=2\& $\mathrm{dn}=1 \& \mathrm{yo}=\% \mathrm{E} 6 \% \mathrm{~B} 0 \% 91 \% \mathrm{E} 4 \% \mathrm{BA} \% 8 \mathrm{~B} \% \mathrm{E} 8 \% \mathrm{~A} 8 \% \mathrm{~B} 4 \% \mathrm{E} 8 \% \mathrm{~A} 8 \% 9 \mathrm{~F} \% \mathrm{E} 6 \% \mathrm{~B} 3 \% 95 \& \mathrm{x}=48 \& \mathrm{y}=$ $10 \& \mathrm{ia}=03 \& \mathrm{ph}=\& \mathrm{ky}=\& \mathrm{page}=1 \& \mathrm{vm}=02$ [https://perma.cc/A6TA-6WDU].

277. Id. art. 221.

278. Id. art. 231; Osaka Kōtō Saibansho [Osaka High Ct.] Apr. 12, 2005, Hei 16 (ra) No. 1317, 894 RŌDŌ HANREI [Rōhan] 14.

279. Saikō Saibansho [Sup. Ct.] Feb. 22, 2001, Hei 12 (kyo) No. 10, 1057 HanreI TAIMUZU [HANTA] 144.

280. See Saikō Saibansho [Sup. Ct.] Apr. 3, 1956, Shou 56 (gyō-su) No. 2, 32 GyōSEI JIKEN SAIBANREISHŪ [GYŌROKU] (No. 4) 539.

281. Takizawa, Bunsho Teishutsu Meirei (2), supra note 271, at 99; Nichibenren Symposium Report, supra note 73 , at 14. 
some attorneys state courts never authorize categorical requests, but require identification of each specific document. ${ }^{282}$ Other practitioners report courts ordering production of documents that will explain certain points, e.g., production of documents showing comparative salary information in a dispute alleging gender discrimination in the workplace. ${ }^{283}$

Where a party is unable to either identify the document or satisfactorily describe its contents, Article 222(1) provides that the petitioner may request the possessor of the documents provide written information enabling further identification. ${ }^{284}$ The code, however, offers no recourse when a litigant refuses, and practitioners report the courts are reluctant to use the procedure. ${ }^{285}$

The (iii) "possessor" of the document has been defined as the person with the "right to dispose of" (shobunken) the document. ${ }^{286}$ The petitions typically offer conclusory statements identifying the plaintiff, defendant, or third-party as the "possessor" of the document. ${ }^{287}$

The specificity required for the petitioner's statement of the (iv) facts to be proven (shomei subeki jijitsu) from the requested documents is more controversial. ${ }^{288}$ The courts are clear that a petitioner may seek production of documents relating to issues for which they bear the burden of proof. ${ }^{289}$ Beyond that, it varies.

In a suit where plaintiffs sought to enjoin operation of a nuclear reactor based on safety concerns, a Tokyo High Court required plaintiff-petitioners to show the concrete facts relating to the structure of the reactors and safety mechanisms to be proven by the documents in order to require their production. ${ }^{290}$ In contrast, in an environmental pollution suit, an Osaka High Court found it sufficient for petitioners to state generally the facts to be proven by production of defendants' documents relating to pollution levels. ${ }^{291}$ The Osaka court stated the obvious: a requirement that the petitioner state specific facts to be proven by production of the documents they have never seen makes it impossible to file the petition in asymmetric litigation. ${ }^{292}$

282. Attorney interviews, supra note 27.

283. Id.

284. Nichibenren Symposium Report, supra note 73, at 14.

285. Id.

286. Yamada, supra note 275.

287. Osaka Bengōshikai, Bunsho Teishutsu Meirei: Moushitate no TeBIKi, Honsho Hakkō no Mokuteki to Riyō no Shikata (2017).

288. Id.; Takizawa, Bunsho Teishutsu Meirei (2), supra note 271, at 99.

289. Tōkyō Kōtō Saibansho [Tōkyō High Ct.] Mar. 15, 1958, Showa Toukou JiHOU [MinJI] 34, 1-3, 39; Takizawa, Bunsho Teishutsu Meirei (2), supra note 271, at 99.

290. Tōkyō Kōtō Saibansho [Tōkyō High Ct.] May 22, 1972, Sho 47 (ra) No. 55, 277 HanRei TAIMUZU [HANTA] 132; Yamada, supra note 275.

291. Osaka Kōtō Saibansho [Osaka High Ct.] Mar. 6, 1978, Sho 52 (ra) No. 120, 359 HANReI TAIMUZU [HANTA] 194; Yamada, supra note 275.

292. Osaka Kōtō Saibansho [Osaka High Ct.] Mar. 6, 1978, Sho 52 (ra) No. 120, 359 Hanrei TAIMUZU [HANTA] 194; Yamada, supra note 275. 
Stating the section (v) basis for the respondent's legal duty to produce the requested document requires the petitioner identify which section of Article 220 petitioner relies on in making the request. The purpose is to clarify the legal issues for the respondent and the court. ${ }^{293}$ The burden is heightened for those petitions based on a party's general duty to produce documents. Here, the petitioner must show there are no other means, e.g., a court or bar associationcommission to produce documents, that will enable the party to offer the document(s) in question into evidence. ${ }^{294}$ In other words, petitioners must prove they have tried everything else. It is a method of last resort.

With this information, the court typically reviews the petition and any response and decides the matter without oral argument. ${ }^{295}$ The court may, however, request the party in possession to produce documents for in camera review to determine whether to order production. ${ }^{296}$

If the court finds the petition is well-founded, Article 223 provides that the court may order production of documents, with or without redactions. ${ }^{297}$ When issuing the order, the courts may specify methods for copying and review. ${ }^{298}$ Practitioners suggest that if documents are ordered produced, the order typically requires that they be produced to the court. ${ }^{299}$ As with court commissions, production to the court does not, in and of itself, result in consideration by the court. A proponent of the evidence will typically offer the document, or a portion of it, into evidence during oral argument, as well as attach copies to written offers of proof. ${ }^{300}$

What sets this procedure apart is that there are consequences for refusing to respond: adverse inferences and monetary sanctions. ${ }^{301}$ If a party, upon receipt of an order for production, fails to produce the document, Article 224 authorizes a court to deem true those facts sought to be proven by production of the documents, or a court may deem a party's claims regarding those facts true. ${ }^{302}$ If

293. Yamada, supra note 275.

294. Id.

295. Minji Soshō Kisoku [Civil Litigation Rules] Art. 140; Takizawa, Bunsho Teishutsu Meirei (2), supra note 271, at 100.

296. Minjı SoshōHō [Minsohō] [C.Civ.Pro.] Law No. 109 of 1996, art. 223(3), translated in JAPANESE L. TRANS., http://www.japaneselawtranslation.go.jp/law/detail/?printID=\&ft=2\&re= $2 \& \mathrm{dn}=1 \&$ yo $=\% \mathrm{E} 6 \% \mathrm{~B} 0 \% 91 \% \mathrm{E} 4 \% \mathrm{BA} \% 8 \mathrm{~B} \% \mathrm{E} 8 \% \mathrm{~A} 8 \% \mathrm{~B} 4 \% \mathrm{E} 8 \% \mathrm{~A} 8 \% 9 \mathrm{~F} \% \mathrm{E} 6 \% \mathrm{~B} 3 \% 95 \& \mathrm{x}=48$ $\& \mathrm{y}=10 \& \mathrm{ia}=03 \& \mathrm{ph}=\& \mathrm{ky}=\&$ page $=1 \& \mathrm{vm}=02$ [https:/perma.cc/A6TA-6WDU].

297. Id. art. 223(1); Mochizuki, supra note 4 at 297.

298. Tōkyō Chihō Saibansho [Tōkyō Dist.Ct.] July 2, 1997, 961 Hanrei TAimuzu [HantA] 277.

299. Takizawa, Bunsho Teishutsu Meirei (1), supra note 49, at 108.

300. Takizawa, Bunsho Teishutsu Meirei (2), supra note 271, at 103.

301. Minsohō (C. Civ. Pro.) art. 224.

302. Minsohō (C. Civ. Pro.) art. 224(1)(3) ("If a party does not comply with an order to submit a document, the court may find the adverse party's allegations concerning the details of said document to be true.”). See Saikō Saibansho [Sup. Ct.] Sept. 28, 1956, Shou 30 (o) No. 494, 63 HANRei taimuZu [Hanta] 47; Saikō Saibansho [Sup. Ct.] Jan 28, 1966, Shou 40 (o) No. 936, 82 
the possessor of the documents is a third party, the third party may be assessed civil fines up to $¥ 200,000$ (approximately $\$ 2,000$ ). ${ }^{303}$ The court has discretion in deciding whether to issue the order, based on its discretion whether to examine evidence or not. ${ }^{304}$ The court is, however, required to state its reason for granting or denying the petition, ${ }^{305}$ and rulings on a petition for an order to produce documents are subject to immediate appeal. ${ }^{306}$

The grounds for appeal are limited. Stand-alone appeals regarding the necessity of discovering the evidence are prohibited. ${ }^{307}$ Determinations regarding the need for discovery of evidence remain the exclusive province of the district court. ${ }^{308}$ Second, absent special circumstances, appellate courts will not review findings of fact, e.g., a district court's determination that a document does or does not contain protected trade secrets following in camera review of the documents. ${ }^{309}$ Finally, while third parties may object to the production of the documents, only the recipient of the order, the possessor of the document in question, may appeal. ${ }^{310}$ In short, interlocutory appeals of orders commonly result in delay, but rarely reversal. Much of the order remains beyond the purview of the appellate courts.

\section{E. Other Methods}

Japan's Code of Civil Procedure authorizes other methods of written discovery. They are categorized here as "other" because practitioners indicate they are rarely used. Japan has also enacted special discovery rules found in a variety of substantive laws, including its intellectual property statutes, that are commonly used. They are categorized here as "other" because of their limited applicability. Both are described briefly here.

\section{Interrogatory-Type Requests}

After the 1996 amendments, Article 163 permits a party, while litigation is

SAIKō SAiBAnSho SAIBANShŪ Minji [ShŪ MIN] 185.

303. Minsohō (C. Civ. Pro.) art. 225 (If a third party does not comply, the court may impose a civil fine of not more than 200,000 yen (approximately $\$ 2,000$ ). Imposition of the fine is subject to immediate appeal).

304. Takizawa, Bunsho Teishutsu Meirei (2), supra note 271, at 100.

305. See Minsohō (C. Civ. Pro.) art. 122 (applied to art. 253 by analogy).

306. Minsohō (C. CIV. Pro.) art. 223(7); Takizawa, Bunsho Teishutsu Meirei (2), supra note 271 , at 102 . The time limit for filing these immediate appeals is typically one week following notice of issuance of the ruling. Minsohō (C. CIV. PRO.) art. 332.

307. Saikō Saibansho [Sup. Ct.] Mar. 10, 2000, Hei 11 (kyo) No. 20, 54 DAISHIN'IN MINJI HANReishū [Minshū] (No. 3) 1073; Takizawa, Bunsho Teishutsu Meirei (2), supra note 271, at 102; Nichibenren Symposium Report, supra note 73, at 16.

308. Nichibenren Symposium Report, supra note 73, at 16.

309. Saikō Saibansho [Sup. Ct.] Nov. 25, 2000, Hei 20 (kyo) No. 18, 62 DAishiN'IN MINJI HANREISHŪ [MinSHŪ] (No. 10) 2507.

310. Aoki, supra note 244, at 115. 
pending, to direct a written inquiry (tōjisha shōkai) to an opposing party seeking a written response related to matters that are "necessary for preparing allegations or proof." 311 The rule then sets out six bases for objecting to the inquiry: the inquiry is (i) "non-specific"; (ii) defamatory; (iii) cumulative; or it (iv) asks for an opinion; (v) is unduly burdensome; or (vi) calls for information that is subject to assertions of privilege. ${ }^{312}$

The device itself is not framed as a discovery device. ${ }^{313}$ It is located in a section of the code addressing procedural rules on "oral arguments and preparation therefor" in trials of the first instance. ${ }^{314}$ As with the courtcommissioned or ordered production of documents, the statutory language requires proof of "need" for the information in order to prepare "allegations or proof." Commentators suggest it is intended less as a means of discovering evidence, and more as a means to exchange information between parties in advance of oral argument before the court. ${ }^{315}$

Litigants do not need court permission to propound these requests, ${ }^{316}$ and respondents do have a "general duty to respond" ${ }^{17}$ according to "principles of good faith and trust." ${ }^{318}$ But again, there are no sanctions for failing to respond. ${ }^{319}$ As a result, practitioners state these requests are rarely productive, and rarely used. $^{320}$ Instead, after suit is filed, litigants commonly invoke the authority of the court to request an opposing party clarify a factual or legal matter pursuant to Article 149. ${ }^{321}$

\section{Pre-Suit Discovery}

With the 2003 amendments adding rules providing for the collection of evidence prior to the filing of an action, ${ }^{322}$ the code now provides six pre-

311. Minsohō (C. Civ. Pro.) art. 163

312. Id. at art. 163(i)-(iv).

313. Nichibenren Symposium Report, supra note 73, at 29.

314. Minsohō (C. Civ. Pro.) art. 163 (Ch. III Oral Arguments and Preparation Therefor. Sec. 2 Briefs).

315. Nichibenren Symposium Report, supra note 73, at 29.

316. Minsohō (C. Civ. Pro.) art. 163.

317. Nichibenren Symposium Report, supra note 73, at 30.

318. Kojima, supra note 28, at 701.

319. Nichibenren Symposium Report, supra note 73, at 30.

320. Id. at 3,30 .

321. Minsohō (C. CIV. Pro.) art. 149 ("The presiding judge... may ask questions of a party or call for a party to give proof with regard to a factual or legal matter, in order to clarify a matter that is related to the litigation. . . . (3) A party may . . . request the presiding judge to ask any necessary questions. .."). Nichibenren Keynote Report, supra note 70, at 3. "The power to demand explication (shakumei-ken) does not have to be exercised in an open court hearing." Kojima, supra note 28 , at 700 .

322. Minsohō (C. Civ. Pro.) art. 132-2-132-9. Otsubo, supra note 94, at 16; Nichibenren Keynote Report, supra note 70 , at 1. 
complaint, discovery devices (utae no teikimae ni okeru shōko shūshū). ${ }^{323}$ The first is the traditional court preservation order discussed above. The remainder are found in a new section of the code titled Dispositions on the Collection of Evidence Prior to the Filing of an Action. ${ }^{324}$

Article 132-2 states that if a party provides a putative defendant with a "notice of anticipated commencement of litigation," 325 the party may propound written inquiries seeking information necessary to bring the action, for a period of four months prior to the filing of the complaint. ${ }^{326}$ A putative defendant may answer and respond with its own inquiries. ${ }^{327}$ Both are to be directed "so as to elicit from that person a written response with regard to particulars that will clearly be necessary for preparing allegations or proof if the action is filed." 328 The evidence sought must be "clearly necessary" and the petitioner must be unable to gather the evidence independently. ${ }^{329}$ At the same time, the proof of necessity required here differs from that required in a post-complaint petition for an order to produce. The standard is not proof of the "need to discover evidence." ${ }^{\prime 30}$ Rather, it is proof of a need for information necessary to prepare claims or proof. ${ }^{331}$

Practitioners suggest the standard is broader than that applied to a petition for an order to produce documents and closer to a relevancy standard. ${ }^{332}$ But the exceptions are equally broad. Respondents may object based on any of the six grounds enumerated in Article 163, including, inter alia, the burden of responding to the request; the inquiry seeks confidential information the disclosure of which would be "substantially detrimental" to the respondent or a third party; or the inquiry seeks disclosure of trade secrets held by the respondent or a third party. ${ }^{333}$ The burden objection is broadly defined: a recipient of the request may object where "the burden in responding is unreasonable or it is deemed unreasonable for other reasons." ${ }^{334}$ The confidentiality objection is broadly defined to include privacy concerns, which are balanced against the need for the information. ${ }^{335}$

323. See supra text accompanying notes 94 to 98; Nichibenren Symposium Report, supra note 73, at 2-3.

324. Minsohō (C. Civ. Pro.) art. 132-2-132-9.

325. Otsubo, supra note 94 , at 16.

326. See, e.g., Minsohō (C. CIV. Pro.) art. 132-2; Yabuki, supra note 138, at 17.

327. Minsohō (C. Civ. Pro.) art. 132-3.

328. Id. at arts. 132-2, 132-3.

329. Otsubo, supra note 94, at 19.

330. See Minsohō (C. Civ. Pro.) art. 181.

331. Nichibenren Symposium Report, supra note 73, at 9.

332. Id.

333. Minsohō (C. CIV. Pro.) art. 132-2(i)-(iii); Otsubo, supra note 94, at 19.

334. Gengai in Okeru Saiban no Jōhō Shūshū ya Saiban no tame no Shōko nado Shūshū no Arikata wo Meguru Mondai, 25 RonKyū JuRISTo 124, 136 (Panel Discussion (Spring 2018)) [hereinafter Juristo Panel Discussion].

335. Id. 
As with the post-complaint interrogatories, the code does not require the courts to authorize the requests for parties to propound them. But the code also provides no sanctions if a respondent fails to respond. ${ }^{336}$ As with the postcomplaint interrogatories, practitioners are more likely to file suit and then invoke the authority of the court to request an opposing party clarify a factual or legal matter pursuant to Article 149. ${ }^{337}$

Prior to filing the complaint, the code also authorizes parties, following notice to a putative opposing party, to petition the court to commission: production of specified documents; an organization to search its records and provide specified information; an expert report; or a court officer to inspect a place or thing. ${ }^{338}$

Where it is possible to obtain information via a bar association-mediated request, courts have refused these commissions, and there are, again, no formal sanctions for a party refusing to respond to the request. ${ }^{339}$ Practitioners are, instead, more likely to request the discovery once the lawsuit has been filed. They note there is a potential cost to ignoring a voluntary request from the presiding judge as the court may decide "whether to find allegations of fact to be true ... in light of the entire import of oral arguments and the results of the examination of evidence." 340

\section{Discovery in Intellectual Property Cases}

Apart from the Code of Civil Procedure and the Attorney Act, various statutes authorize courts to order production of documents and conduct in camera reviews of the documents requested. ${ }^{31}$ Japan's Patent Act is representative of these statutes, and why they contain special discovery rules. ${ }^{342}$ When the Patent Act was enacted in 1959, the Code of Civil Procedure authorized orders to produce only the four specific types of documents discussed above. ${ }^{343}$ None of them permitted discovery of information relating to damages. Article 105 in the Patent Act rectified that: it specifically authorized orders to produce documents necessary to prove damages. ${ }^{344}$ Following the 1996 amendments to the Code of Civil Procedure, the Diet added language to the Patent Act and other intellectual property statutes authorizing production of documents relating to infringement. ${ }^{345}$

336. Nichibenren Symposium Report, supra note 73, at 7.

337. Minsohō (C. CIV. Pro.) art. 149.

338. Id. art. 132-4(i) - (iv); Yabuki, supra note 138, at 17; Otsubo, supra note 94, at 19.

339. Otsubo, supra note 94 , at 19.

340. Minsohō (C. Civ. Pro.) art. 246.

341. See supra notes 111-117 and accompanying text.

342. See also Chosakukenhō [Copyright Act], Law No. 48 of 1970, art. 114-3, translated in JAPANESE L. TRANS., http://www.japaneselawtranslation.go.jp/law/detail/?ft=2\&re=2\&dn= $1 \& \mathrm{yo}=$ Copyright + act $\& \mathrm{x}=0 \& \mathrm{y}=0 \& \mathrm{ia}=03 \& \mathrm{ja}=04 \& \mathrm{ph}=\& \mathrm{ky}=\&$ page $=1 \quad[\mathrm{https}: / /$ perma.cc/E $8 \mathrm{NM}-$ BR4S].

343. See infra Part I.A.

344. See infra Part I.A.

345. See Nihon Benrishikai, Chisai Soshō ni Okeru Bunsho Teishutsu Meirei ni Kan Suru 
The current Patent Act now provides:

In litigation involving the infringement of a patent or the violation of an exclusive license, the court, at the motion of a party, may order a party to submit documents that are needed to prove the infringement or to calculate the damages caused by the infringement; provided, however, that this does not apply if the person in possession of the document has a legitimate reason for refusing to submit them. ${ }^{346}$

The statute goes on to authorize the court, if necessary, to order a party in possession of the document(s) to produce them for in camera review to determine whether to issue the order for production. ${ }^{347}$ It also authorizes a court, if necessary, to disclose the documents to the parties or their representatives in order to hear arguments regarding the appropriateness of an order to produce. ${ }^{348}$

As with the Code of Civil Procedure, Article 105 of the Patent Act requires a court to find that the production requests are "necessary" to order production. As with the Code of Civil Procedure, the Patent Act provides grounds to object. The stated language for the objections is, however, remarkably ambiguous: a party may object for any "legitimate reason." ${ }^{449}$ Courts and scholars have interpreted this as requiring a balancing test, weighing on a case-by-case basis the disadvantage to the possessor of the document arising from disclosure of the trade secret compared to the disadvantage to the litigant from its non-disclosure. ${ }^{350} \mathrm{In}$ intellectual property cases, the courts analyze the need for the discovery, including whether there are alternative forms available, the nature of the confidential information, and the harm from disclosure. ${ }^{351}$ As set out below, litigants invoke these rules regularly to petition the courts to compel production of documents, with limited success.

\section{DISCOVERY IN JAPAN—THE RULES IN PRACTICE}

Data regarding use of these discovery devices is spotty. The Nichibenren maintains comprehensive data regarding bar association requests. Data from the courts is more limited. But combined with practitioner commentary, the available

Chōsa, Kenkyū Oyobi Teigen, supra note 271.

346. ТоккYO-HŌ [Patent Act], Law No. 121 of 1959, art. 105(1), translated in JAPANESE L. TRANS., http://www.japaneselawtranslation.go.jp/law/detail/?ft $=2 \& \mathrm{re}=2 \& \mathrm{dn}=1 \& \mathrm{yo}=\% \mathrm{E} 7 \% 89 \%$ B $9 \%$ E $8 \%$ A $8 \%$ B 1 \% E $6 \%$ B $3 \% 95 \& \mathrm{x}=0 \& y=0 \& i a=03 \& \mathrm{ja}=04 \& \mathrm{ph}=\& \mathrm{ky}=\& \mathrm{pag} \mathrm{e}=1$ [https://perma.cc/VHK9-KVVY].

347. Id. art. 105(2).

348. Id. art. 105(3).

349. Id. art. 105.

350. Nihon Benrishikai, Chisai Soshō ni Okeru Bunsho Teishutsu Meirei ni Kan Suru Chōsa, Kenkyū Oyobi Teigen, supra note 271 (citing Heisei 11 Hōritsu Kaisei Dai 41 Go, Dai 4 Sho, Tokkyo nado no Kenri Shingai ni Tai Suru Kyūsai Sochi no Kakuju 46, Sangyō Zaisanken Hō (Kōgyō Shoyūkenhō) no Kaisetsu).

351. Id. at 15-19. 
information paints a picture of limited but meaningful discovery of documents in most cases, with practitioners relying on a few principal discovery devices.

According to practitioners, the pre-suit discovery devices are onerous and rarely used. ${ }^{352}$ Practitioners will propound pre-suit discovery, the other side will object; the courts will hold a hearing and seek to negotiate a response; the opposing party will produce marginally relevant information, and the four-month time period for pre-suit discovery will have lapsed precluding follow-up. ${ }^{353}$

Practitioners suggest that, in practice, courts may issue pre-suit requests to produce documents; but they do not grant requests for information from organizations or entities, expert statements, or inspections. ${ }^{354}$ They also caution that use of pre-suit discovery can impede pre-suit settlement negotiations. ${ }^{355}$

\begin{tabular}{|l|l|l|}
\hline \multicolumn{3}{|c|}{$\begin{array}{c}\text { No. of Pre-Suit Evidence Collection } \\
\text { Requests Compared to Cases Filed in } \\
\text { District Court }\end{array}$} \\
\hline 2009 & 89 & 847,145 \\
\hline 2010 & 78 & 817,062 \\
\hline 2011 & 66 & 743,589 \\
\hline 2012 & 87 & 668,883 \\
\hline 2013 & 87 & 611,751 \\
\hline 2014 & 72 & 580,546 \\
\hline 2015 & 55 & 577,531 \\
\hline 2016 & 62 & 581,470 \\
\hline 2017 & 71 & 593,796 \\
\hline 2018 & 78 & 588,904 \\
\hline
\end{tabular}

Supreme Court statistics support this commentary. For the ten-year period ending in 2018, the court reports an average of less than 75 petitions for court-ordered, pre-complaint discovery per year. ${ }^{356}$ Over the same period, civil litigants filed an average of 661,068 cases per year in the district courts, ${ }^{357}$ meaning that litigants used these devices in less than 0.01 percent of the cases filed. For all intents and purposes, the rules are dead letter. ${ }^{358}$

Practitioners suggest the use of post-suit interrogatory requests is similarly limited. ${ }^{359}$ While there is no publicly available data quantifying how often they are used and refused, practitioner surveys are indicative.

352. Yabuki, supra note 138, at 17; Otsubo, supra note 94, at 19; Nichibenren Symposium Report, supra note 73, at 2, 13, 32-33. Attorney interviews, supra note 27.

353. Attorney interviews, supra note 27.

354. Nichibenren Symposium Report, supra note 73, at 32.

355. Nichibenren Keynote Report, supra note 70, at 3.

356. Sup. Ct. Data, [Shiryō 5] Dai 3 Kai Oyobi Dai 4 Kai HōKokusho ni Oite Shiteki Shita ChōKIKa YōIn no KeIZOKUTEKi Kenshō [Graph 5] Utae Teikimae no ShōKo Shūshū Shobun no SHInJUKENNSŪ, http://www.courts.go.jp/vems_lf/hokoku_08_siryou5.pdf [https://perma.cc/CFH2-LNAB] [hereinafter Sup. Ct. DATA, [SHIRYō 5]].

357. Sup. Ct., [DAi 1-2 Hyō] Jiken no Shurui to Shinju Kensū no Suit - SAikō, Zenkōtō NADO, СHIHŌ, KANI SAIBANSHO, https://www.courts.go.jp/app/files/toukei/328/011328.pdf; http://www.courts.go.jp/app/sihotokei_jp/list?filter\%5Btype $\% 5 \mathrm{D}=1 \&$ filter $\% 5 \mathrm{ByY}$ ear $\% 5 \mathrm{D}=201$ $8 \&$ filter $\% 5$ ByCategory $\% 5 \mathrm{D}=1 \&$ filter $\% 5 \mathrm{BmYear} \% 5 \mathrm{D}=\&$ filter $\% 5 \mathrm{BmMonth} \% 5 \mathrm{D}=\&$ filter $\% 5 \mathrm{~B}$ mCategory $\% 5 \mathrm{D}=[$ https://perma.cc/FSC7-6XDM] [hereinafter SuP. CT. DATA, [DAI 1-2 HYō]].

358. See Sup. Ct. DATA, [SHIRYō 5], supra note 357.

359. Attorney interviews, supra note 27. 
Local bar associations have surveyed attorneys to find out when these inquiries have actually worked, with limited reports of success. ${ }^{360}$ On the whole, practitioners state, uniformly, that the pre-complaint petitions for discovery and post-complaint interrogatory-type requests are rarely used. ${ }^{361}$ The procedural constraints and lack of sanctions for failing to respond render them an exercise in futility. The Nichibenren has proposed amendments authorizing court intervention and the imposition of sanctions for failure to respond, without success. $^{362}$

But not all is lost. In a 2018 Nichibenren symposium on discovering information in civil litigation, practitioners suggested that there are two effective methods for discovering evidence: first, seeking a commission from the court requesting documents; and, second, seeking an order to produce documents. ${ }^{363}$

Practitioners interviewed for this research expanded on this and separately identified five principal means for discovering information and documents: (a) petitions to the court to exercise its authority to clarify facts and issues; (b) courtcommissioned requests; (c) bar association-commissioned requests; (d) courtordered preservation of documents; and (e) court-ordered production of documents. ${ }^{364}$ The next section addresses the statistical and anecdotal evidence regarding these five devices.

\section{A. Judicial Inquiries \& Burdens of Proof}

There is no data on the courts' exercise of its authority to seek clarification of the facts, only anecdotal evidence. ${ }^{365}$ But practitioners report routinely requesting the courts seek clarification of factual matters either through examination of witnesses or production of documents by a party to the lawsuit. ${ }^{366}$ The anecdotal evidence suggests petitions for clarification are a principal means of discovering information in routine litigation. ${ }^{367}$

Their efficacy depends on the judge and the cooperation of the opposing party. ${ }^{368}$ Some attorneys suggest that if the document or information is potentially dispositive, judges will request its production "because the judges

360. Nichibenren, Minji Saiban ni okeru Shōko Shūshū no Jüjitsu no tame ni,1-5 (July 18, 2018), https://www.nichibenren.or.jp/library/ja/publication/booklet/data/symposium.pdf [https://perma.cc/QT45-S6DQ] [hereinafter Symposium Supplementary Materials].

361. Nichibenren Symposium Report, supra note 73, at 3.

362. Id. at 30 .

363. Id. at 3 .

364. Attorney interviews, supra note 27.

365. Minji SoshōHō [Minsohō] [C.Civ.Pro.] Law No. 109 of 1996, art. 149, translated in JAPANESE L. TRANS., http://www.japaneselawtranslation.go.jp/law/detail/printID=\&ft=2\&re= $2 \& \mathrm{dn}=1 \& \mathrm{yo}=\% \mathrm{E} 6 \% \mathrm{~B} 0 \% 91 \% \mathrm{E} 4 \% \mathrm{BA} \% 8 \mathrm{~B} \% \mathrm{E} 8 \% \mathrm{~A} 8 \% \mathrm{~B} 4 \% \mathrm{E} 8 \% \mathrm{~A} 8 \% 9 \mathrm{~F} \% \mathrm{E} 6 \% \mathrm{~B} 3 \% 95 \& \mathrm{x}=48$ $\& \mathrm{y}=10 \& \mathrm{ia}=03 \& \mathrm{ph}=\& \mathrm{ky}=\&$ page $=1 \& \mathrm{vm}=02$ [https://perma.cc/A6TA-6WDU].

366. Attorney interviews, supra note 27.

367. Id.

368. Id. 
want to know." ${ }^{369}$ The key is to convince the judge that the evidence may be dispositive. ${ }^{370}$ Others emphasize the limits of this type of inquiry. Some report that because attorneys answer the requests for information, they "typically yield little useful information." 371

The plain language of the code also limits the production of information or documents. It authorizes the judge to "encourage," not compel, production of evidence for the purposes of clarifying, not discovering, disputed facts and issues. ${ }^{372}$

The parties may respond out of a fear of antagonizing the judge, but the courts also face pressure to constrain their requests. Judges have faced claims for damages for impermissible use of this authority to seek clarification. ${ }^{373}$ In 2016, a Kobe district court ruled that a summary court judge's ex parte encouragement of a defendant to invoke prescription, a statute of limitations defense, was an illegal exercise of this authority, and awarded the plaintiff $¥ 55,000$ (approximately \$550) in compensation. ${ }^{374}$ Appellate courts, including the Supreme Court, reversed the award. ${ }^{375}$ But some courts still refrain from interfering, particularly early in the proceedings, in the name of party autonomy. ${ }^{376}$ Practitioners suggest it is not possible to rely solely on the courts' right to seek clarification to discover relevant information. ${ }^{377}$

At the same time, judicial intervention makes all the difference in some cases. In some cases, courts will utilize presumptions or shift the burden of proof, obviating the need for discovery. ${ }^{378}$ In highly specialized cases such as medical malpractice, courts have employed doctrines akin to res ipsa loquitur to hold that if a plaintiff shows a procedural mishap followed by worsening symptoms, the court may "infer" negligence and causation. ${ }^{379}$ In cases where a creditor wrongfully exercised preservation rights, when in fact there was no outstanding debt, courts have presumed negligence. ${ }^{380}$ In cases where a document contained in a real estate registry was fraudulently altered, courts have presumed negligence

369. Id.

370. Id.

371. Comer \& Yakura, supra note 2, at 23.

372. Minjı SoshōHō [Minsohō] [C.Civ.Pro.] Law No. 109 of 1996, art. 149, translated in JAPANESE L. TRANS., http://www.japaneselawtranslation.go.jp/law/detail/?printID=\&ft=2\&re= $2 \& \mathrm{dn}=1 \& \mathrm{yo}=\% \mathrm{E} 6 \% \mathrm{~B} 0 \% 91 \% \mathrm{E} 4 \% \mathrm{BA} \% 8 \mathrm{~B} \% \mathrm{E} 8 \% \mathrm{~A} 8 \% \mathrm{~B} 4 \% \mathrm{E} 8 \% \mathrm{~A} 8 \% 9 \mathrm{~F} \% \mathrm{E} 6 \% \mathrm{~B} 3 \% 95 \& \mathrm{x}=48$ $\& \mathrm{y}=10 \& \mathrm{ia}=03 \& \mathrm{ph}=\& \mathrm{ky}=\&$ page $=1 \& \mathrm{vm}=02 \quad[\mathrm{https}: /$ perma.cc/A6TA-6WDU].

373. Kobe Chihō Saibansho [Kobe Dist. Ct.] Feb. 23, 2016, Hei 26 (wa) no. 1738, 2317 HANREI JIHŌ [HANJI] 111.

374. Id.; Saito, supra note 195, at 246.

375. Saito, supra note 195, at 243.

376. Nichibenren Symposium Report, supra note 73, at 8, 18-19.

377. Id.

378. Mark Ramseyer, The Effect of Universal Health Insurance on Malpractice Claims: The Japanese Experience, 2 J. LEGAL ANALYSis 621, 675 (2010).

379. Id. (citing Tōkyō D. Ct., June 7, 1967, 485 HANRei JiHō [HANJI] 21).

380. Saikōsai [Sup. Ct.] Jan. 22, 1990, Hei Gan (o) no. 1546, 1340 HANREI JiHō [HANJI] 100. 
on the part of the registrar in failing to supervise those examining the registry. ${ }^{381}$

In other cases, courts will shift the burden of proof based on express statutory authority. Japan's Act on Securing Compensation for Automobile Accidents imposes strict liability on the driver of a vehicle to compensate for damage arising from its operation, unless the owner or driver proves they exercised due care or another party failed to do so. ${ }^{382}$

Following amendments in 2006 and 2014, Japan's Financial Instruments Exchange Act imposes civil liability on issuers of publicly traded securities for disclosures containing materially misleading representations. ${ }^{383}$ Defendants avoid liability by proving that they did not "intentionally or negligently" make the misleading statement. ${ }^{384}$ Similarly, after the 2015 amendments to the Unfair Competition Prevention Law, if a plaintiff proves ownership of a trade secret improperly acquired by a defendant, and defendant had the ability to produce products incorporating such trade secrets, the burden of proof shifts to the defendant to show "whether or not it used such trade secrets." 385

The bottom line is that judges have the authority to investigate facts, and anecdotal reports suggest that litigants commonly petition the courts to exercise this authority, but the efficacy of doing so varies. It depends on the judge and their willingness to intervene, and the litigant's willingness to ignore the court's "encouragement" to produce relevant information. Separately, in certain types of cases, the courts will presume facts or shift the burden of proof to obviate the need for discovery. Both, however, remain the exception and not the norm. Courts utilize doctrines akin to res ipsa loquitur in exceptional cases. They shift the burden of proof to defendants in other exceptional cases where the legislature has decided to facilitate the mediation or litigation of claims. But there is no evidence to suggest that this obviates the need for litigants to discover relevant information in most cases.

381. Tōkyō Kousai [Tōkyō High Ct.], Oct. 28, 1992, Hei 3 (ne) no. 3544, 809 HANReI TAIMUZU [HANTA] 127.

382. Jidousha Songai Baishou Hoshou Hou [Act on Securing Compensation for Automobile Accidents], Law No. 97 of 1955, at art. 3, translated in JAPANESE L. TRANS., http://www.japanese lawtranslation.go.jp/law/detail/?ft=2\&re $=2 \& \mathrm{dn}=1 \& \mathrm{yo}=\% \mathrm{E} 8 \% 87 \% \mathrm{AA} \% \mathrm{E} 5 \% 8 \mathrm{~B} \% 95 \% \mathrm{E} 8 \% \mathrm{BB}$ $\% 8 \mathrm{~A} \% \mathrm{E} 6 \% 90 \% 8 \mathrm{D} \% \mathrm{E} \% \mathrm{AE} \% \mathrm{~B} 3 \% \mathrm{E} 8 \% \mathrm{~B} 3 \% \mathrm{~A} 0 \% \mathrm{E} 5 \% 84 \% 9 \mathrm{~F} \% \mathrm{E} 4 \% \mathrm{BF} \% 9 \mathrm{D} \% \mathrm{E} 9 \% 9 \mathrm{~A} \% 9 \mathrm{C} \%$ $\mathrm{E} 6 \% \mathrm{~B} 3 \% 95 \& \mathrm{x}=0 \& \mathrm{y}=0 \& \mathrm{ia}=03 \& \mathrm{ja}=04 \& \mathrm{ph}=\& \mathrm{ky}=\& \mathrm{page}=1$ [https $/ /$ perma.cc/CX3X-6B6R].

383. KINYŪ SHŌHIN TORIHIKI Hō [Financial Instruments and Exchange Act ("FIEA")], Law No. 25 of 1948, at art. 21-2; Financial Services Agency, Kinyū ShōHin Torihiki Hō to No Ichibu wo Kaisei Suru Hōritsu ni KaKawaru Setsumei Shiryō, in http://www.fsa.go.jp/ common/diet/ 186/01/setsumei.pdf [https://perma.cc/VD63-82BE].

384. KINYŪ SHŌHIN TORIHIKI Hō [Financial Instruments and Exchange Act (the "FIEA")], art. 21-2(2)

385. Fusei Kyōsō BōShi-HŌ [Unfair Competition Prevention Act], Law No. 47 of 1993, art. 5-2, translated in JAPANESE L. TRANS., http://www.japaneselawtranslation.go.jp/law/detail/? $\mathrm{ft}=2 \&$ $\mathrm{re}=2 \& \mathrm{dn}=1 \& \mathrm{yo}=$ Unfair + Competition + Prevention + Act $\& \mathrm{x}=0 \& \mathrm{y}=0 \& \mathrm{ia}=03 \& \mathrm{ja}=04 \& \mathrm{ph}=\& \mathrm{ky}=\&$ page=1 [https://perma.cc/H3W8-9DA2]; Yasuhiro Sato, Minji Keiji Sekinin Tsuikyū ni Atatte no Pointo, Bus. L. J. 31, 34 (Lexis Japan May 2016). 


\section{B. Court Commissioned Requests}

Practitioners, instead, point to other devices for discovering information in civil litigation, including litigant petitions for court-commissioned requests for information and production of documents. ${ }^{386}$

There is, again, no data regarding the use of these discovery devices, but the literature suggests that practitioners routinely seek court commissions to produce third-party records. This includes production of police reports, tax records, and registration documents from government agencies, and bank, phone, and health care records from private entities. ${ }^{387}$

Some see less potential liability in responding to a court request to produce documents than responding to a bar association-mediated request, and they will encourage the court commission. ${ }^{388}$ Court commissions are now common enough that banks and other companies will include in their consumer contracts terms reserving a right for the company to produce information relating to the account in response to court-commissioned requests. ${ }^{389}$

Separately, both public and private institutions have issued guidelines for responding to such requests. The Japan Medical Association has, for example, issued a "Policy Related to the Provision of Medical Information." ${ }^{390}$ The Ministry of Justice has issued a notice "About the Disclosure of Non-Prosecuted Incident Records to Victims and Others." 391 The Labor Standards Monitoring Bureau has issued guidance regarding court-commissioned requests for production of documents. ${ }^{392}$ Practitioners report that Section 27 of the Tokyo District Court, the section dedicated to adjudicating traffic accidents, processes large volumes of petitions for court-commissioned production of medical and traffic accident records. ${ }^{393}$

The information available is limited, but it supports several conclusions regarding the use of court-commissioned discovery. First, these requests are common in common litigation.

Second, whether seeking business records or documents that are the subject of dispute, the courts expect litigants to use these voluntary requests prior to and

386. Attorney interviews, supra note 27.

387. Tōkyō Dist. Ct. Civ. Sec. Prac. Committee, supra note 165, at 4-9.

388. Attorney interviews, supra note 27.

389. Juristo Panel Discussion, supra note 334, at 124-141.

390. Nihon Ishi Kai, Shinryō Jōhō no Teikyō in Kansuru Shishin (Dai 2) (Oct. 1, 2002), www.med.or.jp [https://perma.cc/9VS2-FYW4].

391. Disclosure of Non-Prosecution Case Records, The Ministry of Justice, http://www. moj.go.jp/EN/keiji1/keiji_keiji23.html [https://perma.cc/MPF7-AXYK].

392. Anzen Eisei Bu, Saibansho Kara no Bunsho Sōfu Shokutaku nado he no Taiō ni Kakawaru Hyōjun Jimu Shori Yōryō, HeISEI 27 NEN 5 GATSU, https://www.mhlw.go.jp/english/ index.html [https://perma.cc/WE5N-PL9T].

393. Bengoshi Yamanaka Riji no Kotsu Jikō Sōdan HP, yamanaka-jiko.jp [https://perma.cc/ 927V-EU4K]. 
sometimes concurrent with petitions seeking court-ordered production of documents. Practitioners note that the data on medical malpractice preservation orders is inconclusive because defendants voluntarily produce the documents requested. Judicial decisions note litigants withdrawing petitions for orders to produce because the respondent has voluntarily produced the requested item.

Third, given their common usage and more lenient review by the court, they are often broader in scope than the specified documents requested in preservation or production orders. Practitioners, representing recipients of these requests, report that they commonly receive requests that are "excessive" or overly broad. ${ }^{394}$ There is no request for "all relevant documents," but there may be requests for certain categories of documents.

Finally, practitioners report increasing objections to court commissions following enactment of Japan's 2005 Personal Information Protection Act. ${ }^{395}$ While still common, an increased awareness of the risks associated with producing third-party information has decreased willingness to respond to court commissions for information or documents.

Practitioners chafe at the increasing number of objections, and the lack of sanctions for non-compliance, ${ }^{396}$ and the Nichibenren has long proposed amendments codifying sanctions for failure to respond, to no avail. ${ }^{397}$

\section{Bar Association Requests for Information}

There is one discovery device for which there are good statistics: the one mediated by the Nichibenren. Practitioners describe the bar association requests for information as another primary means to obtain information. ${ }^{398}$ They suggest it is commonly used to find names and addresses for the purposes of litigating or negotiating disputes. ${ }^{399}$ Bar association requests are commonly used to access routine business records, including accident reports in personal injury cases and bank account statements in debt collection cases. They are sent to brokerages to confirm possession of stock; to phone companies to confirm phone numbers; and insurance companies to confirm applicable insurance contracts. ${ }^{400}$

The statistics support this commentary. A 2019 Attorney White Paper suggests most of the requests go to the police, financial institutions, and prosecutor's offices. ${ }^{401}$ Nichibenren statistics also show year-on-year increases in attorney requests to local bar associations to commission requests for information. ${ }^{402}$

394. Nichibenren Panel Discussion, supra note 171, at 27.

395. Id.; Jurisuto Panel Discussion, supra note 334, at 125.

396. Attorney interviews, supra note 27.

397. Nichibenren Symposium Report, supra note 73, at 11.

398. Wagnild, supra note 1, at 10-11; Attorney interviews, supra note 27.

399. Nichibenren Symposium Report, supra note 73, at 4.

400. Abe \& Yamauchi, supra note 217, at 108; Attorney interviews, supra note 27.

401. Nichibenren, Bengoshi Hakusho [Attorney White Paper] 228 (2019).

402. Nichibenren, Bengoshikai kara Shōkai wo Uketa Minna sama he, https://www. 


\begin{tabular}{|l|l|}
\hline \multicolumn{2}{|c|}{2019 Requests to Bar Associations } \\
by Category \\
\hline Police & $31.9 \%$ \\
\hline Financial Institutions & $31.2 \%$ \\
\hline Prosecutors & $10.9 \%$ \\
\hline Other & $7.4 \%$ \\
\hline Communications-Related Entities & $6.4 \%$ \\
\hline Transportation-Related Entities & $5.5 \%$ \\
\hline Medical Institutions & $3.0 \%$ \\
\hline Ministry of Justice & $1.7 \%$ \\
\hline Local Governments & $1.5 \%$ \\
\hline Public Health Depart. & $0.6 \%$ \\
\hline
\end{tabular}

\begin{tabular}{|l|l|}
\hline \multicolumn{2}{|c|}{$\begin{array}{c}\text { Commission } \\
\text { Requests Received } \\
\text { by Bar Associations }\end{array}$} \\
\hline 2013 & 144,350 \\
\hline 2014 & 160,493 \\
\hline 2015 & 176,334 \\
\hline 2016 & 187,219 \\
\hline 2017 & 210,862 \\
\hline 2018 & 216,474 \\
\hline 2019 & 221,928 \\
\hline
\end{tabular}

Comparing these requests to the number of new cases filed during the same period, one finds attorneys turn to their local bar association in about 3 out of 10 cases filed. If one considers the types of information typically requested - accident reports, bank records, phone records, medical records, and the like - the information available suggests most requests involve cases classified by the Japanese courts as "common litigation," i.e., disputes between individuals. ${ }^{403}$ If so, the data, in the table below, suggest attorneys pursue bar association-mediated requests in most litigation involving private parties. ${ }^{404}$

nichibenren.or.jp/activity/improvement/shokai/qa_b.html (last visited. Jan. 21, 2021).

403. The Supreme Court defines "common litigation" as cases involving legal disputes between individuals. Saikōsaibansho, MinJI Soshou No SHURUI [https://perma.cc/L8NZ-NBJH]. 404. Sup. Ct., [DAi 1-2 Hyō] Jiken no Shurui to Shinju Kensū no Suit, supra note 357. 


\begin{tabular}{|l|c|c|c|c|}
\hline & $\begin{array}{c}\text { New Cases filed } \\
\text { in District Court } \\
\text { (Civil \& Admin.) }\end{array}$ & $\begin{array}{c}\text { New Cases filed } \\
\text { in District Court } \\
\text { (Civil) }\end{array}$ & $\begin{array}{c}\text { New Cases filed } \\
\text { in District } \\
\text { Court } \\
\text { (Common } \\
\text { Litigation) }\end{array}$ & $\begin{array}{c}\text { Commission } \\
\text { Requests } \\
\text { Received by } \\
\text { Bar } \\
\text { Associations }\end{array}$ \\
\hline 2013 & 611,756 & 607,232 & 147,390 & 144,350 \\
\hline 2014 & 580,550 & 576,051 & 142,487 & 160,493 \\
\hline 2015 & 577,534 & 572,420 & 143,817 & 176,334 \\
\hline 2016 & 581,470 & 576,642 & 148,306 & 187,219 \\
\hline 2017 & 593,794 & 589,229 & 146,678 & 210,862 \\
\hline 2018 & 588,921 & 584,856 & 138,444 & 216,474 \\
\hline 2019 & 596,374 & 592,640 & 134,934 & 221,928 \\
\hline
\end{tabular}

Practitioner commentary regarding the efficacy of these requests is mixed. Some suggest that recipients are increasingly willing to respond. ${ }^{405}$ Others report an increasing number of objections. ${ }^{406}$ The difference appears to stem from the type of information requested.

Practitioners suggest the system works well for commonly requested business records, e.g., bank records in the will contest, and medical records in the personal injury case. ${ }^{407}$ Objections arise to particularized requests seeking information for which the possessor of the documents may have a proprietary interest in the information, a duty of confidentiality, or concerns about the liability associated with production of personally identifiable information. ${ }^{408}$ Despite the objections, the statistics suggest that bar association requests are used regularly because they offer distinct advantages. While they function similarly to court-commissioned requests for documents, there is no need to inform the opposing party. ${ }^{409}$ There is no need to involve the court, and there is no obligation to share the information gained, beneficial or otherwise, with the opposing party. ${ }^{410}$

In some respects, this discovery device functions like a non-party request for production of documents in the United States, but without the notice and without the "subpoena power." comes not from an attorney, functioning as an officer of the court, but rather from the public law mandate given to the bar associations in Japan to function as a regulatory authority. They discipline attorneys as necessary, and they act as gatekeepers for discovery requests. The remarkable feature about these requests

405. Takizawa, Bengoshikai Shōkai, supra note 230, at 102.

406. Attorney interviews, supra note 27.

407. Juristo Panel Discussion, supra note 334, at 125; Attorney Interviews, supra note 27.

408. Juristo Panel Discussion, supra note 334, at 125; Attorney Interviews, supra note 27.

409. Attorney interviews, supra note 27.

410. Id.; Juristo Panel Discussion, supra note 334, at 139.

411. See Fed.R.Civ.P. 45. 
is the near absolute discretion afforded the bar association. The statutory language in the Attorney Act provides no guidance. The bar association may refuse a request if it is "inappropriate" (tekitō de nai). ${ }^{412}$ The statute similarly provides no guidance regarding a recipient's right to object to production, yet they can and do, and do so with little risk of reprisal. The statute, again, offers no authority to sanction failures to respond. ${ }^{413}$

Practitioners report change. They report increasing efforts by bar associations to file suit to impose costs on recipients who fail to respond, and a growing body of case law recognizing a recipient's potential liability. But the courts have not yet imposed the same. ${ }^{414}$ As a result, the Nichibenren continues to press for legislative amendments codifying sanctions for failure to respond. ${ }^{415}$

\section{Preservation Orders}

Practitioners describe the petition to preserve evidence as a potent weapon, but one that is rarely used. ${ }^{416}$ As set out above, the procedural hurdles are many, and the demands on the judiciary are large. In contrast, scholars have suggested that, because this is one of the few methods of production that a court can compel and impose sanctions for noncompliance, it is commonly used as a means of pretrial discovery by Japanese attorneys. ${ }^{417}$ The discrepancy can be explained by the disparate use of the device.

Practitioners note typical cases where a court may issue an order to preserve evidence requiring a witness to appear in court for examination. They include instances where a witness may become unavailable because of an impending and long-term transfer overseas, age, or medical condition. ${ }^{418}$ Typical cases where the court may order production of documents include instances where the evidence shows a risk of spoliation or expiration of a document retention policy resulting in destruction of the document. ${ }^{419}$ Of the two, ninety percent of preservation orders relate to inspection of documents. ${ }^{420}$

These "typical" cases are atypical litigation. Most cases do not present a demonstrable risk of witnesses becoming available or spoliation. At the same

412. Bengoshi-HŌ [Attorney Act], Law No. 205 of 1949, art. 23-2

413. See discussion of judicial decisions supra Part III.C.

414. Attorney interviews, supra note 27.

415. Nichibenren Symposium Report, supra note 73, at 5-6.

416. Id. (noting many experienced attorneys have never filed a petition seeking court-ordered preservation of documents).

417. Takaaki Hattori \& Dan Fenno Henderson, Civil Procedure in Japan $\S 6.03$ n.10 (explaining that since expansive discovery devices similar to those in the United States have yet to be adopted in Japan, attorneys have resorted to using preservation of evidence even though it was not meant to be utilized as a discovery tool).

418. Marumichi, supra note 135, at 50-51; Tōkyō Dist. Ct. [Tōkyō Dist. Ct.] June 4, 1971653 HANREI JIHŌ [HANJI] 97.

419. Marumichi, supra note 135 , at 50- 51 .

420. Id. 
time, there are certain types of cases where petitions to preserve evidence are more common. Practitioners suggest litigants commonly seek preservation orders in medical malpractice cases, based on accepted concerns regarding spoliation of medical records. ${ }^{421}$ Practitioners litigating securities fraud claims also report commonly using preservation orders. ${ }^{422} \mathrm{~A}$ former judge has suggested that most preservation orders issued involve medical malpractice cases, ${ }^{423}$ and the published studies of preservation orders only examine medical malpractice cases. A 2006 study found that the courts issued preservation orders in $35.5 \%$ of all medical malpractice cases filed. ${ }^{424}$ More recent statistics, shown below, suggest such petitions for preservation and their grant rate have declined, but their use is still routine. ${ }^{425}$

\begin{tabular}{|l|l|l|l|l|l|l|l|l|l|}
\hline \multicolumn{1}{|c|}{$\begin{array}{c}\text { Number of Medical Cases involving } \\
\text { Preservation Petitions \& Percentage Granted }\end{array}$} \\
\hline 2009 & 2010 & 2011 & 2012 & 2013 & 2014 & 2015 & 2016 & 2017 & 2018 \\
\hline 247 & 217 & 158 & 147 & 129 & 117 & 116 & 101 & 98 & 79 \\
\hline $26.8 \%$ & 24.2 & $20.5 \%$ & $17.9 \%$ & $16.6 \%$ & $15.3 \%$ & $15.4 \%$ & $13.5 \%$ & $13.0 \%$ & $10.3 \%$ \\
\hline
\end{tabular}

At the same time, judges and practitioners suggest that orders seeking to preserve internal company documents in complex litigation have become more common. ${ }^{426}$ They detail instances where the courts have ordered time records and computer documents preserved in employment litigation. ${ }^{427}$ Courts have ordered inspection of industrial equipment in a workplace accident. ${ }^{428}$ They have ordered preservation of nursing home visitation logs in will contests. ${ }^{429}$ They have ordered forensic examination of computers in copyright infringement cases. ${ }^{430}$

There are also media reports of court personnel hauling out boxes of documents from corporate offices in trade secrets cases and conducting nation-

421. Id.

422. Attorney interviews, supra note 27.

423. Saibankan ga Shōko Hozen De Keisatsu ni Irei no 'Tachiiri', Shihōken no 'Sontaku Shinai' Shisei no Araware ka, LIVEDOOR NEwS (Feb. 27, 2018), http://news.livedoor.com [https://perma.cc/9KMT-AWER].

424. Saikō Saibansho [Sup. Ct.], 1.3 Dai Isshin ni OKeru Senmon Soshou Jiken no TOUKEI Ni TSUiTE (2006), http://www.courts.go.jp/vcms_lf/20505003.pdf [https://perma.cc/ VW9H-BTNT].

425. Saikō Saibansho [Sup. Ct.], Saiban no Jinsokuka ni Kakawaru Kenshou ni

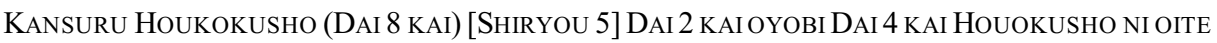
Shiteki Shita Choukika Youin no KeIzoku teki Kenshou, http://www.courts. go.jp/vcms_lf/hokoku_08_siryou5.pdf [https://perma.cc/YV3P-CQZK].

426. Marumichi, supra note 135, at 51; Saibankan ga Shōko Hozen De Keisatsu ni Irei no

'Tachiiri', supra note 423.

427. Attorney interviews, supra note 27.

428. Id.

429. Id.

430. Id. 
wide inspections of "Internet cafés" in another. ${ }^{431}$ There are recent media reports of Tokyo District Court personnel attempting to execute a preservation order at the Tokyo Chiyoda District Prosecutors Office - "an unusual step" from "a traditionally passive judiciary.", ${ }^{, 32}$

In that case, plaintiff filed a complaint seeking damages for injuries alleged to have occurred when the police used excessive force. Plaintiff and the court sought production of photographs and videotape of the incident. ${ }^{43}$ The prosecutor's office refused to produce the same arguing that doing so would infringe on third-party privacy interests and interfere with an ongoing investigation. ${ }^{434}$ The court granted plaintiff's petition for a preservation order but was unable to execute it. ${ }^{435}$ Court personnel entered the prosecutor's office and served the order, but the prosecutors refused to produce the requested photographs and videotapes. ${ }^{436}$

The media reports, practitioner commentary, and statistics offer insufficient information to draw firm conclusions. But they support three generalizations: First, outside of the medical malpractice context, preservation orders are rare enough to generate newspaper headlines. The fact that some experienced litigators report never having filed a petition for a preservation order supports the conclusion that preservation orders are the exception rather than the rule. ${ }^{437}$ The exceptional nature of this discovery is understandable. Requiring court personnel to execute a preservation order by examining witnesses and going to businesses to inspect documents ensures that the costs of a preservation order, to the judiciary, will outweigh the benefits in most cases. In most civil litigation, the parties will rely on other methods of discovering evidence.

The second generalization is that litigants increasingly seek, in complex litigation, discovery of internal corporate documents using preservation orders. ${ }^{438}$ Practitioners are uniform in their statements that the use of preservation orders is becoming more common. Some attorneys now report filing petitions for them regularly. ${ }^{439}$

Finally, the Tokyo District Court's attempt to execute a preservation order at the Tokyo Chiyoda District Prosecutor's office highlights a thread common throughout discovery practice in Japan. The courts may aggressively seek production of documents if they believe doing so is necessary, even if it means taking on an intransigent prosecutor's office.

At the same time, practitioners suggest the courts are generally reluctant to

431. Marumichi, supra note 135, at 51.

432. Tōkyō Chisai ga Keishicho ni Tachiiri, to Keisatsukan Utaeta Saiban Meiguri, AsAHI SHINBun (Feb. 23, 2018).

433. Id.

434. Id.

435. Id.

436. Saibankan ga Shōko Hozen De Keisatsu ni Irei no 'Tachiiri', supra note 423.

437. Attorney interviews, supra note 27.

438. Id.

439. Id. 
take on recalcitrant parties, whether they are private parties or the state. ${ }^{440}$ The courts are reluctant to impose adverse inferences, even when recipients refuse to cooperate. ${ }^{441}$ Some experienced practitioners interviewed for this research had never heard of a court imposing an adverse inference. ${ }^{42}$ Instead, the courts resort to cajoling parties to comply with preservation orders by emphasizing that doing so will remove the risk of allegations of spoliation. ${ }^{443}$ But if the litigants are willing to suffer that consequence, as the Tokyo Chiyoda Prosecutor's Office case highlights, there is little a court can do.

\section{E. Orders to Produce Documents}

As with the preservation orders, practitioners and judges describe petitions for orders to produce documents as "important" and "effective," even if not commonly used. ${ }^{444}$ Western commentators describe the order to produce as a "major tool for collecting evidence from an opposing party or third person." ${ }^{445}$ As discussed below, that is a stretch, but the emphasis is not misguided. These orders give teeth to a principal reform from the 1996 amendments, imposing on litigants a general duty to produce documents.

Information regarding the number of petitions filed and the number issued is limited, but what there is suggests that the courts rarely order production of documents. In a report compiled by the Secretariat of the Supreme Court for the ten-year period from 2005-2014, the courts received, on average, 3,800 petitions a year, with the numbers

\begin{tabular}{|l|l|}
\hline \multicolumn{2}{|l|}{$\begin{array}{l}\text { Petitions for } \\
\text { Production of Documents }\end{array}$} \\
\hline 2005 & 4,304 \\
\hline 2006 & 3,945 \\
\hline 2007 & 4,310 \\
\hline 2008 & 4,131 \\
\hline 2009 & 3,951 \\
\hline 2010 & 4,286 \\
\hline 2011 & 3,890 \\
\hline 2012 & 3,569 \\
\hline 2013 & 3,065 \\
\hline 2014 & 2,824 \\
\hline
\end{tabular}

440. Id.

441. Id.

442. Id.

443. Minjı SoshōHō [Minsohō] [C.Civ.Pro.] Law No. 109 of 1996, art. 149, translated in JAPANESE L. TRANS., http://www.japaneselawtranslation.go.jp/law/detail/?printID $=\& \mathrm{ft}=2 \& \mathrm{re}=2 \&$ $\mathrm{dn}=1 \& \mathrm{yo}=\% \mathrm{E} 6 \% \mathrm{~B} 0 \% 91 \% \mathrm{E} 4 \% \mathrm{BA} \% 8 \mathrm{~B} \% \mathrm{E} 8 \% \mathrm{~A} 8 \% \mathrm{~B} 4 \% \mathrm{E} 8 \% \mathrm{~A} 8 \% 9 \mathrm{~F} \% \mathrm{E} 6 \% \mathrm{~B} 3 \% 95 \& \mathrm{x}=48 \& \mathrm{y}=$ $10 \& \mathrm{ia}=03 \& \mathrm{ph}=\& \mathrm{ky}=\&$ page $=1 \& \mathrm{vm}=02 \quad$ [https://perma.cc/A6TA-6WDU] (provides for adverse inferences, and may be applied to procedures involving preservation of evidence. The court may, but is not required, to adopt an adverse inference). See, e.g., Osaka Chihō Saibansho [Osaka Dist. Ct.], Sept. 10, 1971, 274 HANRei TAimuzu [HANTA] 337 (finding the defendant refused to permit inspection sought by a competitor in patent litigation based on legitimate concerns about disclosure of business and technical secrets, such that it was not appropriate to adopt an assumption based on plaintiff's claims of infringement).

444. Takizawa, Bunsho Teishutsu Meirei (1), supra note 48, at 107; Attorney interviews, supra note 27 .

445. Wagnild, supra note 1, at 12. 
decreasing over time. ${ }^{446}$ A more recent study examined the number of petitions for orders to produce filed in both civil and administrative actions over the tenyear period from 2009 to 2018. Those numbers again showed a significant decrease over time, averaging approximately 3,100 petitions per year in civil suits and 140 per year in administrative actions. ${ }^{47}$

\begin{tabular}{|l|l|l|l|l|l|l|l|l|l|l|}
\hline \multicolumn{10}{|c|}{ Petitions for Orders Requiring Production of Documents } \\
\hline & $\mathbf{2 0 0 9}$ & $\mathbf{2 0 1 0}$ & $\mathbf{2 0 1 1}$ & $\mathbf{2 0 1 2}$ & $\mathbf{2 0 1 3}$ & $\mathbf{2 0 1 4}$ & $\mathbf{2 0 1 5}$ & $\mathbf{2 0 1 6}$ & $\mathbf{2 0 1 7}$ & $\mathbf{2 0 1 8}$ \\
\hline $\begin{array}{l}\text { Civil } \\
\text { petitions }\end{array}$ & 3951 & 4286 & 3890 & 3569 & 3065 & 2824 & 2825 & 2574 & 2433 & 2207 \\
\hline $\begin{array}{l}\text { Admin } \\
\text { petitions }\end{array}$ & 120 & 141 & 182 & 131 & 171 & 130 & 152 & 159 & 119 & 131 \\
\hline Total & 4071 & 4427 & 4072 & 3700 & 3236 & 2954 & 2977 & 2733 & 2552 & 2338 \\
\hline
\end{tabular}

An earlier study examined the results of the petitions filed in the Tokyo District Court seeking orders to produce documents. In 2006, litigants filed a total of 380 petitions. ${ }^{448}$ In eighty-seven, litigants withdrew the petitions before the court rendered a decision. The court resolved 264: by issuing a decision (kettei) in fifty-three and a judgment on the merits (hanketsu) in 124. In the fiftythree where the court issued a stand-alone discovery decision: it ordered production in twenty cases and denied the petition in thirty, leaving three unaccounted. ${ }^{449}$

If one compares the number of newly filed cases involving private disputes ( $u$ go jiken shinju kensū) filed in 2006 in Tokyo District Court, 30,140, with the number of petitions filed, litigants sought orders to produce documents in $1.26 \%$ of all cases filed. ${ }^{450}$ If one assumes litigants primarily file petitions for orders to produce documents in complex litigation where the issues or damages warrant the expense, ${ }^{451}$ and if one assumes that most complex litigation ends up in Tokyo,

446. Saikō Saibansho [Sup. Ct.] Saiban no Jinsokuka ni KaKawaru Kenshou ni Kan SURU HOKUSHO (DAI 6 KAI), http://www.courts.go.jp/about/siryo/hokoku_08_hokokusyo/index. html [https://perma.cc/KE3E-W7QK]; Nichibenren Symposium, supra note 73, at 2.

447. Saikō Saibansho [Sup. Ct.] Saiban no Jinsokuka ni KaKawaru Kenshou ni Kan Suru Hokusho, [Shiryou 5] Dai 3 Kai oyobi Dai 4 Kai Houkokusho ni oite Shiteki Shita CHOUKIKA YouIn No KeIZOKUTEKi KenshOu, HYOu 8, http://www.courts.go.jp/vems_lf/hokoku_ 08_siryou5.pdf [https://perma.cc/7ULR-5AR4].

448. Judge Noriaki Sudo, Minji Jijitsu Nintei to Risshō Katsudō Dai 1 Kan, in Bunsho Teishutsu Meirei no Genjō to Kadai 282 (Nichibenren Symposium 2018).

449. Id.

450. Id.

451. Supreme Court statistics for 2018 show that $72.8 \%$ of all district court cases filed sought less than $\$ 100,000$, and thirty percent of all cases filed are filed in Tōkyō District Court. Saikō Saibansho [Sup. Ct.] [Shiryō 2-6] [Shiryō 2-1-2], JiKenRUiKeIBETSU JiKen JōKYō (MinJi DAI Isshin, Gyōsei Dai isshin, Kasai Jinji (2) (2018); Chinō SAIBAnsho Kannaibetsu Jikennsū 
then even that small number overstates the percentage of petitions filed nationally.

There is separate data for intellectual property cases. A 2015 report by the Japan Federation of Patent Agents surveyed decisions available on the Japanese Supreme Court's public database of judicial opinions from 1981-2014..$^{452}$ The report suggests that orders to produce documents in intellectual property cases are not uncommon, and that courts grant them, but usually as they relate to damages.

The courts rarely order discovery related to infringement, finding it "unnecessary." More specifically, from 1981-2014, the courts denied petitions to order production of documents in thirty-three cases. Of those, twenty-eight were denied because the court found the requests were unnecessary; the documents would not influence the result; factual determinations could adequately be made based on the existing documentary record; the court found no compensable legal claim; or the parties failed to demonstrate a need for the discovery in the underlying petition. ${ }^{453}$ Practitioners suggest, in general, courts will order production of documents when it is the "only" (yuitsu) evidence on point. ${ }^{454}$

The study found twenty-two cases in which the court ordered production of documents. ${ }^{455}$ Of those cases, only two sought documents relating to proof of infringement; twenty related to proof of damages. ${ }^{456}$ Equally important, of those twenty-two cases, in only four did the defendant comply with the court order. ${ }^{457}$ In the remainder, defendants elected not to produce the documents but, instead, to have the court enter an adverse inference. ${ }^{458}$ The report speculates that, in many cases, plaintiffs' claims underestimate defendants' actual profits such that it makes strategic sense to suffer the adverse inference. ${ }^{459}$

Outside of IP litigation, practitioners report that compliance rates depend on the type of case. Businesses that rely on government licenses to conduct business are more likely to comply with court orders to preserve or produce documents than those that do not. ${ }^{460}$

While the data suggests court orders to produce documents are outliers, and

NADO, (MINJI DAI ISSHIN) (2018), http://www.courts.go.jp/vcms_lf/hokoku_08_siryou2.pdf [https://perma.cc/K4QG-4852].

452. Nihon Benrishikai, Chisai Soshō ni Okeru Bunsho Teishutsu Meirei ni Kan Suru Chōsa, Kenkyū Oyobi Teigen, supra note 271.

453. Id. at App. 3.

454. Attorney interviews, supra note 27.

455. Id.

456. Id.

457. Id.

458. Id. The court issues the adverse inference in patent cases pursuant to Code of Civil Procedure Article 224. See Minji SoshōHō [Minsohō] [C.Civ.Pro.] Law No. 109 of 1996, art. 149, translated in JAPANESE L. TRANS., http://www.japaneselawtranslation.go.jp/law/detail/?printID=\& $\mathrm{ft}=2 \& \mathrm{re}=2 \& \mathrm{dn}=1 \& \mathrm{yo}=\% \mathrm{E} 6 \% \mathrm{~B} 0 \% 91 \% \mathrm{E} 4 \% \mathrm{BA} \% 8 \mathrm{~B} \% \mathrm{E} 8 \% \mathrm{~A} 8 \% \mathrm{~B} 4 \% \mathrm{E} \% \mathrm{~A} 8 \% 9 \mathrm{~F} \% \mathrm{E} 6 \% \mathrm{~B} 3 \% 9$

$5 \& \mathrm{x}=48 \& \mathrm{y}=10 \& \mathrm{ia}=03 \& \mathrm{ph}=\& \mathrm{ky}=\& \mathrm{page}=1 \& \mathrm{vm}=02$ [https:/perma.cc/A6TA-6WDU].

459. Id.

460. Attorney interviews, supra note 27. 
anecdotal reports suggest many practitioners never file these petitions, ${ }^{461}$ the judicial decisions and anecdotal reports suggest they are central to discovery practice, in part because litigants negotiate discovery in the shadow of the law.

Practitioners report seeing more court-ordered production now than in the past and more court orders that are broader in scope than in the past. ${ }^{462}$ Some now regularly draft petitions seeking court-ordered production of documents for the purposes of convincing an opposing party to voluntarily produce the same in response to an informal written request (yōseisho). ${ }^{463}$ They do not file the petitions unless they have to, as doing so inevitably delays the proceedings. ${ }^{464}$ As discussed above, court orders compelling production of documents are subject to interlocutory appeal and typically delay the proceedings by several months. ${ }^{465}$ But they now file them if necessary, and then negotiate a response. ${ }^{466}$

Practitioners can negotiate discovery in the shadow of the law because courts are ordering production of specified documents. In contested financial transactions, courts have ordered banks to produce some due diligence documentation. ${ }^{467}$ In employment discrimination cases, courts have ordered employers to produce time cards, salary information, and meeting records from harassment investigation committees. ${ }^{468}$ In commercial litigation, courts have ordered companies to produce documents related to management buyouts and board of director meeting minutes. ${ }^{469}$ In consumer litigation, courts have ordered production of customer files and audio recordings of customer transactions. ${ }^{470} \mathrm{In}$ medical malpractice cases, courts have ordered production of portions of adverse incident investigation reports. ${ }^{471}$ In products liability cases, courts have ordered

461. OSAKA BENGŌSHIKAI, supra note 287.

462. Attorney interviews, supra note 27.

463. Id.

464. Id.

465. Id.

466. Id.

467. Saikō Saibansho [Sup. Ct.] Nov. 30, 2007, Hei 19 (kyo) no. 5, 61 SAIKō SAIBAnSho Minji Hanreishū [Minshū] (No. 8) 3186; Saikō Saibansho [Sup. Ct.] Nov. 25, 2008, Hei 20 (kyo) no. 18, 62 Saibansho Minji Hanreishū [Minshū] (No. 10) 2507 (ordering production of bank assessment documents). Compare Saikō Saibansho [Sup. Ct.], Nov. 12, 1999, Hei 11 (kyo) No. 2, 1017 Hanrei taimuzu [Hanta] 102, with Saikō Saibansho [Sup. Ct.] Dec. 14, 2000, Hei 11 (kyo) no. 35, 54 Saikō SAibansho minji hanreishū [Minshū] (No. 9) 2709 (declining to order production of bank ringisho and related opinion documents).

468. Saikō Saibansho [Sup. Ct.] Dec. 19, 2013, Hei 25 (kyo) no. 6, 1423 Hanrei TAimuzu [HAnTA] 138; Osaka Kōtō Saibansho [Osaka High Ct.] July 18, 2013, Hei 25 (ra) no. 565, 2224 HANRei JiHō [HANJI] 52; Osaka Kōtō Saibansho [Osaka High Ct.] Apr. 12, 2005, Hei 16 (ra) no. 1317, 894 RōDō HANRei [RoHan] 14.

469. Kobe Chihō Saibansho [Kobe Dist. Ct.] May 8, 2012, Hei 16 (mo) no. 230, 1395 [Kinshou] 40; Tōkyō Chihō Saibansho [Tōkyō Dist. Ct.] June 15, 2012, 339 ShIRYōBan ShōJı HŌMU [SHIRYŌSHŌJI] 210.

470. Attorney interviews, supra note 27.

471. Tōkyō Kousai [Tōkyō High Ct.] July 15, 2003, Hei 15 (ra) nos. 831 \& 900, 1145 HANREI 
production of photographs contained in accident investigation reports and employee and witness statements. ${ }^{472}$ In intellectual property cases, courts have ordered production of chat logs relating to the product. ${ }^{473}$

In administrative litigation, courts have ordered production of Ministry of Justice documents and accounting records for politicians serving in local government. ${ }^{474}$ In environmental litigation, courts have ordered production of documents containing pollution data from waste disposal facilities. ${ }^{475}$ In civil suits relating to criminal prosecution, courts have ordered production of petitions for warrants and victim statements. ${ }^{476}$

The above list is a long one, but, even at that, it is merely representative. The evidence is clear: Courts in Japan order production of documents, including documentation that would likely be protected in other jurisdictions. ${ }^{477}$ Second, they do so, most often, in complex litigation where the monetary or societal value of the case is high and the evidentiary value of the documents great. Finally, the analysis, most often, boils down to a fact-intensive balancing test. Courts analyze the need for the evidence in the case compared to the need for confidentiality, privacy concerns, and other objections raised by the producing parties. If the need outweighs those concerns, the courts order the documents produced. ${ }^{478}$

\section{CONCLUSION}

In some respects, discovery in Japan has come to resemble that found in the United States. If the opposing party has information you need, you can send them interrogatories. If the opposing party has documents you need, you can request their production. If a third party has documents you need, you can send a thirdparty request, via the court or bar association.

In terms of pre-complaint discovery, Japan's Code of Civil Procedure now

TAIMUZU [HANTA] 298. See also Leflar, supra note 18, at 100.

472. Nayoga Chihō Saibansho [Nagoya Dist. Ct.] Nov. 17, 2008, Hei 19 (mo) no. 697, 1333 HANREI TAIMUZU [HANTA] 270.

473. Chiteki Zaisan Kōtō Saibansho [Intellectual Property High Ct.] Aug. 8, 2016, Hei 28 (u) no. 10038 .

474. Compare Saikō Saibansho [Sup. Ct.] Oct. 29, 2014, Hei 26 (gyou-fu) no. 3, 2247 HANREI TAimuzu [HANTA] 3, with Saikō Saibansho [Sup. Ct.] Nov. 10, 2005, Hei 17 (gyou-fu) no. 2, 1210 HANREI TAIMUZU [HANTA] 72 (interpreting different local ordinance and declining to order production).

475. Fukuoka Kōtō Saibansho [Fukuoka High Ct.] Apr. 25, 2003, Hei 15 (ra) no. 32, 1855 HANRei JiHō [HANJI] 114; Tōkyō Chihō Saibansho [Tōkyō Dist. Ct.] Sept. 12, 2003, Hei 12 (mo) no. 14722, 1845 HANREI JiHŌ [HANJI] 101.

476. Saikō Saibansho [Sup. Ct.] July 22, 2005, Hei 17 (kyo) no. 4, 1191 Hanrei TAimuzU [Hanta] 230; Saikō Saibansho [Sup. Ct.] Dec. 12, 2007, Hei 19 (kyo) no. 22, 1261 Hanrei TAIMUZU [HANTA] 155.

477. See Leflar, supra note 18, at 100.

478. Juristo Panel Discussion, Gengai in Okeru Saiban no Jōhō Shūshū, supra note 334, at 137. 
offers more robust discovery than permitted in federal courts in the United States. Potential litigants in Japan may submit pre-complaint interrogatories and request the court commission production of information, documents, inspections, and expert reports, if doing so facilitates a party's formulation of the issues and proof in anticipated litigation. While "all information" used to be "presumptively nondiscoverable," possessed by private persons presumptively discoverable." ${ }^{\prime 40}$ That is the tatemae presented by the rules.

The honne of discovery in Japan is different. Written discovery is routine, but it is limited in scope and dependent on voluntary cooperation. Bar associationmediated requests are commonplace. Attorneys seek production of bank records, medical records, phone records, financial records, etc., and they do so prior to filing suit and without notice to the opposing party. But the recipients of such requests remain free to refuse them, without fear of sanction.

Requests for information maintained by an opposing party are common, but they are also limited in scope, and dependent on voluntary cooperation. Parties routinely request a court commission, i.e., request the voluntary production of, specified information or documents. But respondents, again, remain free to refuse to respond, without sanction. During litigation, the parties may petition the court to invoke its authority to "clarify" contested issues by seeking production of information or specific documents. But the courts exercise broad discretion to examine evidence or not, and, if the courts do seek clarification, the code only authorizes them to "encourage" the parties to produce information or documents.

Parties may request the court order preservation of documents or testimony, and, for this, there are sanctions. But the institutional cost is enormous. If the court orders preservation of documents, judges and court staff generally do the inspection. After the complaint is filed, parties may also petition the court to order production of documents, but respondents routinely object to such petitions, appeal such orders, and courts are loath to fight the battle. Just as crowded dockets have caused Japanese courts to cut back on court-ordered inspections, use of experts, and examination of parties and witnesses during trial proceedings, ${ }^{481}$ courts routinely deny requests for orders to produce documents, finding the discovery "unnecessary." 482

The courts' reluctant participation in the discovery process is understandable. The number of judges is determined by law. The current Court Staffing Act

479. Mochizuki, supra note 3, at 287.

480. Id. at 287-88.

481. The Japanese Federation of Bar Associations, in advocating for an increase in the number of judges, have documented this decline. From 1979 to 2007, court examination of witnesses, including the parties to the litigation, decreased from approximately $30 \%$ to approximately $10 \%$. Court utilization of experts decreased from approximately $2.5 \%$ of all cases filed to $0.75 \%$. The Nichibenren attributes this decline to the increase in the courts' caseload. NiCHIBENREN, https://www.nichibenren.or.jp/library/ja/publication/booklet/data/saibankankensatsukan_zouin.pdf [https://perma.cc/M3DJ-Q2A2].

482. Mochizuki, supra note 3, at 290. 
provides for eight chief judges of the high courts, 2,125 judges, and 927 assistant judges, for a total of 3,060 judges, excluding summary court appointees. ${ }^{483}$ In 2018, there were 588,904 cases filed in the district court and 34,052 cases filed in the appellate courts. ${ }^{484}$ On a per capita basis, each judge added approximately 200 cases to their docket in 2018. In some years, "district court judges (including assistant judges) have decided over 1,100 civil, administrative, and criminal cases per judge per year." ${ }^{485}$

The judiciary simply does not have the resources to conduct discovery in each case, but that is what the Code of Civil Procedure requires them to do. Judges control the process. It is the courts that must approve of and commission "voluntary" requests for information. They must approve of and commission "voluntary" requests for production of documents. They must review and grant or deny petitions seeking clarification of contested issues. They must review and grant or deny petitions seeking orders to preserve evidence. They must review and grant or deny petitions seeking orders to produce documents.

Some have argued one of the great strengths of the Civil Law system is that "[d]igging for facts is primarily the work of the judge." 486 In Japan, it may be a principal weakness. Given an overtaxed judiciary, asking it to act as a gatekeeper in every case for all discovery, save bar association-mediated requests, asks too much. The courts find it easier to seek voluntary cooperation, and where that fails deny court-ordered discovery as "unnecessary." and scholars continue to lament the lack of meaningful discovery in Japan. Practitioners lament the lack of sanctions for refusing to respond to discovery requests and orders. ${ }^{488}$ Practitioners lament the lack of a relevancy standard and inability to seek production of categories of documents: if you don't know the document exists, you are out of luck. ${ }^{489}$ The Nichibenren continues to propose reforms to expand discovery, and the more conservative Ministry of Justice and business groups continue to oppose them, ever distrustful of the type of discovery

483. Saibansho Shokuin Teirn Hō [Court Staff Quota Act], Law No. 53 of 1951, as amended in Law No. 5 of 2019.

484. Sup. Ct., [Dai 1-2 Hyō], Jiken no Shurui to Shinjukensū no Sūi-Saikō, Zenkōtō NADO, CHIHŌ, KANNi SAIBANSHO, supra note 357.

485. See Haley et al., supra note 12 at 4.

486. John H. Langein, The German Advantage in Civil Procedure, 52 U. ChiCago L. Rev. 823-4, 827 (1985) ("by assigning judges rather than lawyers to investigate the facts, the Germans avoid the most troublesome aspects of [Anglo-American] practice ...”).

487. As noted by Japanese civil procedure scholars, "[t]he fundamental policy of the new code is not to make unequivocal directions to the parties but to set up the framework and then to encourage autonomous and cooperative administration among the people concerned in that framework." Kojima, supra note 28, at 717.

488. Attorney interviews, supra note 27.

489. In contrast, one attorney recited experiences where some judges have approved categorical requests seeking production of unspecified documents that demonstrate, e.g., salary differentials in an employee gender discrimination claim against an employer. Id. 
and its abuse found in the United States. ${ }^{490}$

The proposed reforms are piecemeal, and typically involve attempts to add sanctions for refusal to respond to discovery, whether issued by the bar association or court. ${ }^{491}$ Yet, this research suggests the problems run deeper; they are systemic. Adding court-administered sanctions to a discovery process already dependent on the court may encourage cooperation, but it increases the demands on the court. It increases the size of the bottleneck presented by rules requiring courts to negotiate discovery. In routine cases, there simply is not enough time or money for counsel or the courts to engage in individualized attempts to voluntarily negotiate production of information or documents, and, if that fails, to then attempt to compel the same. ${ }^{492}$

Discovery in Japan is inefficient by design, but discovery everywhere is inefficient by design. In any jurisdiction relying on discovery, as opposed to disclosure, litigants in routine cases plow the same ground over and over again. Experienced attorneys practicing employment law propound the same requests for production of information and documents to show discrimination, in case after case. ${ }^{43}$ Experienced personal injury attorneys propound the same requests for production of information and documents to show negligence, in case after case. ${ }^{494}$ Experienced securities practitioners propound the same requests to prove or disprove fraud. ${ }^{495}$ Experienced IP attorneys propound the same requests to prove or disprove infringement and damages. ${ }^{496}$

490. Nichibenren Keynote Report, supra note 70, at 1, 5-6, 14-16; Attorney interviews, supra note 27 .

491. Nichibenren Keynote Report, supra note 70, at 1, 5-6, 14-16.

492. Experienced practitioners lament the absence of discovery and report never having filed a petition seeking an order to produce documents. Attorney interviews, supra note 27.

493. Experienced employment lawyers representing both plaintiffs and defendants, in conjunction with the Advisory Committee on the Federal Rules of Civil Procedure, the National Employment Lawyers Association, and the Institute for Advancement of the American Legal System have developed discovery protocols requiring "substantial mandatory disclosures" from both sides at the beginning of employment cases. Memorandum from Judge David G. Campbell, Chair, Advisory Comm. on Fed. Rules of Civil Procedure, Regarding Proposed Amendments to the Federal Rules of Civil Procedure (June 14, 2014), https://iaals.du.edu/sites/default/files/ documents/publications/2015-04-29-transmittal_to_congress.pdf [https://perma.cc/SQ7H-YM74].

494. Even in complex products liability cases, there is pattern discovery. See, e.g., LARRY L. VARn \& Douglas Danner, PATtern Discovery: Products Liability (2019).

495. Most individual investor claims filed against brokers are governed by mandatory arbitration clauses, and most arbitrations are conducted by the Financial Industry Regulatory Authority ( "FINRA"). FINRA publishes a Discovery Guide that requires firms and associated persons to make initial disclosures of twenty-two types of documents, and the individual investor to disclose nineteen categories of documents. See generally Discovery Guide (2013) - For claims filed on or after December 2, 2013, FINRA, https://www.finra.org/arbitration-mediation/discoveryguide [https://perma.cc/8L6S-C8GZ].

496. The federal court in the District of Delaware mandates initial disclosures in patent litigation by plaintiffs relating to the asserted patents and their patent history and, by defendants 
Most litigation is routine, and much of the discovery requested is standard. Why negotiate it on a case-by-case basis? There is core discovery designed to produce information relevant to common claims and defenses, and it is here that Japan is well-suited to innovate, to turn an inefficient discovery process into a model. With its substantive laws already containing specialized discovery rules, Japan has moved from trans-substantive rules of civil procedure to subject matterspecific rules. ${ }^{497}$ It could make use of that paradigm to turn from discovery to disclosure in routine litigation.

Japan has proven remarkably adept at creating "detailed, clear, public formula" for routine cases. ${ }^{498}$ In the 1960s, Japan established a section of the Tokyo District dedicated to claims involving traffic accidents. ${ }^{499}$ After being overwhelmed by the number of cases, judges expedited discovery by negotiating an agreement with the Tokyo District Public Prosecutors Office and the Tokyo bar associations for prosecutors to produce redacted police reports. ${ }^{500}$ The court also convened a study group, including members of the local bar association, to create and publish standard pleading templates and detailed compensation standards. ${ }^{501}$ This enabled the parties to resolve "the vast majority" of cases, without resort to the courts; the cases that remained were "atypical." 502 In other words, courts and practitioners successfully created uniform disclosure rules and standards for damages in traffic accident cases. ${ }^{503}$ They could create uniform disclosure rules in lieu of most discovery in Japan.

Most litigation in Japan is routine. Studies suggest that approximately twenty percent of the categorized cases on the district courts' 2014 docket related to rent or eviction claims; twenty percent involved claims relating to financial transactions, including promissory notes, deposits, purchase money, surety, loan, and credit-related claims; and ten percent involved tort claims, exclusive of traffic accidents. ${ }^{504}$ The statistics suggest that at least fifty percent of the cases filed are

of core technical documents, including, e.g., operation manuals, product literature, schematics, and specifications. See generally Default Standard For Discovery, Including Discovery Of Electronically Stored Information 4(a), 4(b), https:/www.ded.uscourts.gov/sites/ded/files/ pages/Electronic\%20Discovery\%20Default\%20Standard_0.pdf [https://perma.cc/X8VF-Q8GM].

497. See supra notes 111-119.

498. Daniel Foote, Resolution of Traffic Accident Disputes and Judicial Activism, 25 L. JAPAN 19, 20 (1995) (quoting J. Mark Ramseyer \& Minoru Nakazato, The Rational Litigant: Settlement Amounts and Verdict Rates in Japan, 18 J. LEGAL STUD. 263, 269-70 (1989)).

499. Id. at 24 .

500. Id. at 25 .

501. Id. at 25-27.

502. Id. at 30 .

503. The Japanese Federation of Bar Associations Traffic Accident Consultation Center publishes yearly updates of its 'Redbook' containing these standards. Standards for Determining Damages in Civil Traffic Accident Litigation, NiCHIBENREN, https://n-tacc.or.jp/book\#st-toc-h-3 [https://perma.cc/T9AZ-9BL3].

504. See Manako Kinoshita, The Features of Civil Litigation in Japan, 71 Soc. ScI. Res. (No. 2) 27, 32, Table 2-1 (2020). 
routine. Disclosures of core documents in these cases could also be routine. If fifty percent of core discovery in routine litigation is handled through mandated disclosure, resources remain for the court-negotiated discovery necessary to resolve the atypical cases.

In other words, negotiated protocols for disclosure of core documents in routine litigation would alleviate costs associated with court-directed discovery. It would enable disclosure of relevant information in cases too small to warrant litigating discovery in the courts, and it would free up the courts to better address atypical or complex litigation where the issues warrant sustained judicial management of discovery.

There is admittedly hubris in a scholar from the United States proposing change to civil discovery conducted elsewhere. Yet, different perspectives give rise to different insights, and one following this research is that Japan is wellsuited to move beyond the traditional constraints imposed by trans-substantive rules of civil procedure.

At the same time, this research offers another, more immediate insight: things have changed. Litigants and the courts in Japan have co-opted methods to gather and examine evidence to function as discovery devices. ${ }^{505}$ Discovery in Japan is still limited, but it now happens regularly. And in complex litigation, it may be dispositive. If you can identify a document or discrete category of the documents and prove to the court that it is "necessary," Japanese courts will order discovery. The 1996, and subsequent, amendments to the Code of Civil Procedure have indeed changed the litigation landscape. It may be, as a well-known Japanese scholar has suggested, that discovery in Japan remains akin to kingyo sukui, like fishing for goldfish at a festival where you only catch what you can see and grab with a tiny net. But, in civil litigation now, you might just catch what you need. If litigants in Japan can discover the existence of important documents and gain the time and attention of an overloaded judiciary, there is now discovery to be had.

505. Nichibenren Symposium, Bunsho Teishutsu Meire no Genjō to Kadai 9, https://www. nichibenren.or.jp/library/ja/publication/booklet/data/symposium.pdf [https://perma.cc/98KJKAM4]. 